\author{
DEMOGRAPHIC DYNAMICS, LABOR \\ FORCE PARTICIPATION AND HOUSEHOLD \\ ASSET ACCUMULATION: CASE OF JAPAN
}

\begin{abstract}
Albert Ando
Andrea Moro

Working Paper 5261
NATIONAL BUREAU OF ECONOMIC RESEARCH 1050 Massachusetts Avenue
Cambridge, MA 02138
September 1995

Part of the data used in this analysis is cohort means computed from individual returns from the National Survey of Family Income and Expenditure conducted by the Statistics Bureau of the Japanese Government, to which Ando had access as a member of a team headed by Fumio Hayashi, at the Department of Economics, Osaka University. While we would have preferred to work with somewhat differently organized data, we no longer have individual data and results reported here are restricted to those producible based on the original summary tabulations of the data. This paper relies significantly on the earlier work of Gonzalo Garland. See Ando, Moro, Cordoba and Garland (1995). This paper is part of NBER's research program in Economic Fluctuations. Any opinions expressed are those of the authors and not those of the National Bureau of Economic Research.

(C) 1995 by Albert Ando and Andrea Moro. All rights reserved. Short sections of text, not to exceed two paragraphs, may be quoted without explicit permission provided that full credit, including $($ ) notice, is given to the source. 


\title{
DEMOGRAPHIC DYNAMICS, LABOR FORCE PARTICIPATION AND HOUSEHOLD ASSET ACCUMULATION: CASE OF JAPAN
}

\begin{abstract}
A dynamic model of the demographic structure of Japan is summarized. It is capable of tracing the dynamic development of the Japanese population, including the distribution of families by age, sex, and marital status of the head, as well as by the number and age of children and other dependents. This model is combined with a specification of the processes generating family income and consumption, and then used to generate the pattern of aggregate income, saving and asset accumulation for the period 1985-2090 under alternative fertility assumptions. The results suggest that the saving-income ratio for Japan will increase slightly in the immediate future as the number of children per family declines sharply, and then fall moderately as the proportion of older persons in the population increases. Quantitative results depend critically on the labor force participation rate of older persons and on the probability of older persons merging into younger households. However, unless some major changes in Japanese saving behavior take place, our analysis suggests that Japan will have an unusually high net worth-income ratio as its population stabilizes or begins to decline.
\end{abstract}
Albert Ando Department of Economics University of Pennsylvania Philadelphia, PA 19104 and NBER

\author{
Andrea Moro \\ Department of Economics \\ University of Pennsylvania \\ Philadelphia, PA 19104
}




\section{Introduction}

For a national economy to follow a path of orderly economic progress, one of the essential requirements is that its needs for capital accumulation are more or less matched by the saving generated by society when resources in the economy, especially labor, are fully employed. Since most economists would consider the positive relationship between the growth rate of output in the economy and the investment-output ratio to be a fairly natural implication of production technology and the rational behavior of producers, the above requirement suggests that the saving-income ratio and the rate of growth of income should be positively related in a well-functioning economy.

The above proposition for producers applies to individual firms more or less uniformly since firms do not have obvious phases of a life cycle except at the starting point and those related to the nature of vintage capital owned by them. The positive relationship between the investment-output ratio and the rate of growth of output is therefore thought to hold, at least qualitatively, for the aggregate of all firms in an industry or an economy as well.

The relationship between the rate of growth of income and the saving-income ratio for households is more complex. Other things equal, the higher the expected rate of growth of income in the future, the smaller we expect the current saving-income ratio to be. On the other hand, given the current and expected future level of income, the higher the rate of growth of income has been in the past, the higher the current saving-income ratio is likely to be. This is because, if the past rate of growth of income is higher given the current level of income, that is, if the past level of income is lower, it may be 
presumed that the accumulation of wealth has been lower, and the lower level of wealth reduces the level of current consumption ${ }^{1}$.

Thus, there is little uniformity among households in the relationship between the growth rate of income and the saving-income ratio. Furthermore, each household in society is in a particular phase of its life cycle, and this and other demographic characteristics of each household, such as its marital status, number of children, other membership in the family, have major effects on its current saving-income ratio. The aggregate relationship between the saving-income ratio and the rate of growth of income, therefore, is a result of the aggregation process rather than a reflection of a uniform feature of individual households.

Perhaps the best known theoretical construct explaining the positive correlation between the growth rate of aggregate income and the saving-income ratio was offered some years ago by Modigliani and Brumberg (1980) as an implication of their original formulation of the life cycle theory.

For our purpose, we find it convenient to generalize their proposition somewhat by dividing all households in society into cohorts defined not only by the age of the head but also by other demographic characteristics such as the marital status and sex of the head and the number of children, and note the following definitional relationship:

$$
\frac{S(t)}{Y(t)}=\sum_{a} \sum_{f} w(t, a, f) \frac{y(t, a, f)}{Y(t)} \cdot \frac{s(t, a, f)}{y(t, a, f)}
$$

\footnotetext{
'There may be an element of habit persistence as well.

${ }^{2}$ This formula does not apply when $y(t, a, f)$ is zero. For such cohorts, the cohort saving must be expressed directly as

$$
w(t, a, f) s(t, a, f)
$$

and then divided by $Y(t)$ to be included in the summation on the right hand side of (1). Since $y(t, a, f)$ is a cohort mean and not the income of an individual household, it is very rare that $y(t, a, f)$ is in fact zero.
} 
where $S(t)$ and $Y(t)$ are aggregate saving and disposable income of the household sector, $w(t, a, f)$ is the weight (the total number of families in the cohort defined by the age of the head being $a$ and its demographic characteristics being $f)$, and $y(t, a, f)$ and $s(t, a, f)$ are the mean values of disposable income and saving for the cohort $(a, f)$ in period $t$. Note that $f$ is a vector, so that the summation sign above $f$ is in principle multiple summations. This definitional relationship can serve two distinct purposes. First, it enables us to decompose movement of the aggregate saving-income ratio over time into three factors : movements of the relative size of cohorts (w), the relative level of mean income among cohorts $(y / Y)$, and the relative size of the saving-income ratio among cohorts $(s / y)^{3}$. Second, provided that we have theories and models to generate the size and distribution of population into cohorts, income distribution among cohorts, and the saving-income ratio for cohorts given characteristics of cohorts, we can use this identity to generate the aggregate implications of these theories and models, thus enabling us to study the effects of alternative assumptions and policies at the micro level on aggregate saving behavior. In this paper, we deal with the second of these two types of analysis.

In terms of (1), the Modigliani proposition is that $s / y$ is positive for younger households and very small or negative for older ones, and hence a shift of $w$ from younger cohorts to older ones (due to slower growth of population ) would reduce saving, and so

\footnotetext{
${ }^{3}$ It is clear that this formula can be expanded to accomodate alternative assumptions. For example, suppose that consumption is viewed as depending on lifetime income (yp) rather than on current income (y). We can then write
}

$$
\frac{C(t)}{Y(t)}=\sum_{a} \sum_{f} W(t, a, f) \frac{y(t, a, f)}{Y(t)} \frac{y p(t, a, f)}{y(t, a, f)} \frac{C(t, a, f)}{y p(t, a, f)}
$$

where $C(t)$ is aggregate consumption and $C(t, a, f)$ is the mean consumption for the cohort $(a, f)$ in period $t$. 
does a shift of income from younger cohorts to older cohorts (due to a slowdown of generation specific productivity increases) ${ }^{4}$.

Let us digress to the U. S. case where some familiar attempts somewhat similar to this inquiry already exist. In their recent papers Bosworth, Burtless and Sabelhaus (1991) and Cannari (1994) have investigated whether or not the decline in the saving-income ratio in the U.S. and in Italy during the 30 years ending in 1990 could be attributed to shifts in weight due to a changing demographic pattern of these countries. They focused their attention almost exclusively on the age distribution of the heads of households and did not find that shifts in weights can account for the decline in the aggregate savingincome ratio.

Gokhale, Kotlikoff and Sabelhaus (1994) find that the recent decline in the saving-income ratio in the U.S. can be attributed to a shift of resources from younger families to older households, and to an increase in the consumption-income ratio of these older households when their income and consumption is defined appropriately, due in large part to a rise in medical costs. We are inclined to agree with Gokhale et al. that the earlier papers were too narrowly focused.

In parallel to Gokhale et al., we present in Appendix I a table suggesting that at least a part of the decline in the saving-income ratio in the United States during the past 30 years is due not so much to the aging of the population, but to a shift in the relative

\footnotetext{
${ }^{4} \mathrm{~A}$ substantial part of the current literature on aggregate consumption and saving behavior is based on the assumption of a representative consumer. In such a model, the only productivity increase that can be accomodated must result in a faster rate of growth of income for the representative consumer himself. We refer to this type of productivity increase as "calendar year specific" productivity growth. Modigliani, on the other hand, had in mind a generalized overlapping generations model in which each family lives not two but a multiple number of periods, and when he talked of productivity increase, he supposed that each generation had a fixed pattern of productivity over its life that was not subject to change once the family began its working life, but that the younger generation was always more productive than the preceding one. We refer to this type of productivity increase as "generation specific" productivity growth. We believe that, theoretically, both types of productivity increase may coexist. However, we seldom observe significant dissaving by young families in societies where the aggregate productivity increase is very rapid, such as Japan and Italy from 1960 to 1975. See Ando, Guiso and Terlizzese (1994a). Hence, in this paper, we proceed assuming that the aggregate impact of the negative correlation between the saving-income ratio and income growth within a family is not dominant.
} 
weights among family types, from two parent families to single parent families and to single individuals.

As the birth rate in most OECD countries declines, and the size of the older population becomes larger relative to the younger, working population, economists and the public in general are increasingly concerned that the saving-income ratio may decline sharply and cause serious disequilibrium in these countries. This is perceived as the basic prediction of the life cycle theory of saving. But such a major change in demographic structure is likely to be accompanied by other shifts, such as a decline in the number of children per family, changes in the social convention of work, for example, higher labor force participation of older individuals and perhaps women, counteracting some effects of the aging of the whole population. In other words, shifts in weights in equation (1) may be accompanied by changes in the distribution of income and the saving-income ratios of various cohorts. In this paper, we propose a framework for dealing with their simultaneous movements in response to changes in demographic patterns, and present some results of analyzing a relatively simple case for Japan. ${ }^{5}$

We begin our discussion by briefly looking at what the distribution of weights, income, and the saving-income ratio over cohorts, looked like in Japan in the base year, 1985. We then summarize our model of demographic dynamics to determine the future values of the weights, and our hypotheses for the determination of the distribution of income among cohorts and of the saving-income ratio for individual cohorts. Finally, we report the results of simulating these models together for a sufficiently long period of time to see the consequences of alternative assumptions concerning demographic dynamics.

\footnotetext{
${ }^{5}$ The demographic structure of Japan is much simpler than that of the U. S. because there is virtually no immigration into Japan, and the divorce rate and the birth rate outside marriage are much smaller. Given the homogeneity of the population and the near absence of homeless and other unsettled segments of the population, errors and biases of census counts are a much less serious problem in Japan than in the U.S.
} 


\section{A Preliminary View of the Data}

The basic data sets for our analysis are the National Survey of Family Income and Expenditure for Japan, 1984, and the Final Report of the Population Census of Japan, 1985. The former is a very detailed survey of income and expenditures of families based on a sample of some 54,000 households, and it includes fairly detailed information on the demographic characteristics of households as well as summary information on their assets and liabilities. For the analysis presented here, we have used a combination of estimation results using individual returns obtained in our earlier project and some published tabulations.

In Table 1.A. ${ }^{6}$, we show income, the saving-income ratio, and the net worthincome ratio for Japanese families in 1985 by age and family type. By normal family, we mean all those families headed by a married couple, including nuclear families (those consisting of a married couple and their children 18 years of age and younger) and extended families (nuclear families plus additional dependents, such as grown children, parents of the couple, etc.). We see that those families who belong to the "normal family" group continue to earn sizable income after they reach the age of 60 and 70 , and they continue to save. Looking at these families, one may be tempted to conclude that the life cycle hypothesis does not hold in Japan.

A careful investigation of older households in Japan reveals, however, that those older individuals who have in fact retired tend to merge into younger households, and disappear as independent units. Note that in this survey the person who is earning the highest income in the family is designated as the head of household. A large fraction of those older individuals who do not merge into younger households continue to work. We show in Table 3 the ratio of older individuals who have merged into younger households to the total number of older individuals as of 1979 and in Table 4 the labor force participation rate by age for 1984 . We would like to call the reader's attention to major

\footnotetext{
${ }^{6}$ All Tables are collected at the end of the paper.
} 
differences in the labor force participation rate between the U.S. and Japan. For males aged $70-74$, for instance, the participation rate in the U.S. is .144 , whereas it is .403 for Japan. This very high participation rate of older individuals in Japan has a major consequence for the nature of the impact of the aging of the population. An inspection of Tables 1. A., 3, and 4 makes clear the difficulty of interpreting the pattern shown in Table 1. A. as a simple saving and asset accumulation pattern over life prevailing in Japan.

The saving pattern of households headed by unmarried males is by and large similar to the normal family, and in any event they constitute a very small group of families. We may note that households headed by an unmarried male have a relatively large income and large asset-income ratio. For relatively younger cohorts, this arrangement appears to be the result of a young unmarried male with relatively high income living with his parents, and because of his high income, he is designated as the head of the household. Older ones, on the other hand, result from widowhood or from divorce, and again the single male in question becomes designated as the head only if his income is high. Others, for example, may have grown children whose income is higher and they become designated as heads. For male singles, we note that there are a significant number of them until about 40 years of age, and they save heavily, presumably in preparation for their marriage. In another paper, Ando, Guiso and Terlizzese (1994a) show that similar male individuals living with their parents earning similar levels of income save even more.

Households headed by unmarried females, on the other hand, have much lower income and they dissave. The critical feature to be noticed here is that, in spite of negative saving, these households on average possess significant amounts of assets, and the asset-income ratio increases with age throughout all ages. This is a consequence of a complex process in which female headed households are created by divorce or widowhood, and the older the newly created unmarried female headed household, the larger their starting net worth. At the same time, existing unmarried female headed 
households disappear, partly because of remarriages if they are relatively young, through their merger into younger households especially if they are older and their net worth is small.

\section{Income, Consumption and Asset Accumulation.}

Income received by an individual household whose head is less than 63 years old is described by the following equation

$$
\ln y(t, a, g)=\alpha_{0}+\sum_{i} \alpha_{a(i)} a(i)+\sum_{i} \alpha_{g(j)} g(j)+\sum_{i} \sum_{j} \alpha_{a(i) g(j)} a(i) g(j)+\gamma \cdot t
$$

where $y$ is income before income taxes, $a(i)$ 's are a set of one-zero dummies indicating whether or not a household falls in the age class $i, g(j)$ 's are also a set of one-zero dummies indicating whether or not a household possesses the $j$-th characteristic. In particular, we take into account the number of additional income earners in the family. $\alpha$ 's are the estimated coefficients, $t$ represents time, and $\gamma$ is the rate of growth of income. The interaction terms represent primarily the fact that the age pattern of income depends on the occupation of the worker.

We first apply this equation to individual households in the sample and estimate the coefficients. Since the sample refers to a single year, for estimation purposes, we omit the term $\gamma \cdot t$ from the above equation, and $\gamma$ is separately estimated. The estimation result for the main working group, families whose heads are aged 63 or less, is given as Table 5. A. We must comment on two potential pitfalls of this estimation.

First, this equation ignores the response of the labor supply to the real wage rate.

This seems justified for the main income earner who is primarily responsible for supporting the family, but for secondary workers, this may be a questionable assumption. Our effort to check on this question using two rounds of surveys separated by five years did not indicate that this is a serious problem. Second, if income and life expectancy are 
correlated, coefficients of variable $a$ may be biased. In Ando, Guiso and Terlizzese (1994b) it is shown that the correlation between income and life expectancy does not appear to be present any more. In Japan, however, elderly individuals with relatively low income have a much higher probability of merging into younger households than high income ones. Thus, we must be careful to interpret the result of estimating the above equation as applying to those older individuals maintaining independent households. Income of those who merge into younger households but who continue to work is estimated through the coefficient of one of the g's.

For the purpose of estimating the consumption function, the prediction of equation (2) serves as the measure of current income. Future expected income of the household is constructed by applying (2) with the value of $t$ increased successively, with appropriate choice of $a(i)$ taking on the value " 1 ", and some of the $g$ 's taking on the value "1" or " 0 " multiplied by a probability. This process is continued until the head of the household reaches 63 years old, and then the annualized present value of the sum of expected income thus estimated is defined as the expected future income.

Since the value of $\gamma$ is not estimated, we have used several alternative assumptions in our analysis. The result reported here is based on the assumption that the value of $\gamma$ is equal to the real interest rate implicit in the assumed value of the discount factor. In the remainder of this paper, we denote the prediction of (2) by a plain $y$, and the future expected income constructed as described above by ye.

For those families whose heads are 63 years old or older, we have estimated alternative equations for two distinct groups. For those families whose head is still working, we have estimated an equation similar to equation (2) above. For those families whose heads are fully retired, we have assumed that their pension income will remain the same in the future in real terms. For those who are newly retiring, we have assumed their starting pension to be the same as the level received by currently retired persons one year 
older, increased by the growth in average productivity per capita ${ }^{7}$. If these fully retired families have income from capital, we have assumed that the same level of capital income in real terms will continue to be received until they merge into younger households. This assumption seems reasonable because those families who exhaust their wealth will merge into younger households, while those who remain independent appear to maintain their wealth without reducing it much.

We now come to the determination of the level of consumption. For those families whose heads are 63 years old or less, we have estimated the following type of equation:

$$
\frac{c}{y}(i, j)=\beta_{y}+\beta_{e} \frac{y_{e}}{y}(i, j)+\sum_{i} \beta_{a(i)} a(i)+\sum_{i} \beta_{a(i) v(i, j)} a(i) \frac{v}{y}(i, j)+\sum_{j} \beta_{f(j)} f(j)
$$

where $a(i)$ are, as before, dummies indicating age class; $(c / y)(i, j)$ and $(v / y)(i, j)$ are, respectively, the mean consumption-income ratio and the mean net worth-income ratio for the subgroup of the population defined by the age class $a(i)$ and having characteristic $f(j)$, while $f(j)$ 's are vectors of demographic and other characteristics of families. $g(j)$ and $f(j)$ are not the same set, but they may include common elements. $\beta$ 's are estimated coefficients. The numerical values of estimates are given in Table 5. B.

Since (3) is not explicitly derived as a consequence of an optimization process from a well specified objective function, parameter estimates of a decision rule such as (3) are subject to doubt that they may not be well identified corresponding to parameters of the objective function, and that they may be subject to serious bias if they are interpreted as indicating the marginal effect of a change in the value of variables for which they are coefficients. On the other hand, it is doubtful that we can write a uniform

\footnotetext{
${ }^{7}$ This simple scheme appears to be as reasonable an approximation to the Japanese public pension program embodied in the 1985 reform legislation as possible given the information available in our data.
} 
objective function that applies to all household in a society, and that an estimate of parameters of such an assumed uniform objective function is meaningful (Kirman, 1992). For the purpose of our paper, we assume that a decision rule in the form of (3) is applicable to all individual households, although parameter values may vary from one household to another. Our estimates are then meant to be the weighted average of parameter values for individual households belonging to appropriate subgroups. We discuss briefly below the nature of some possible biases in our estimates of coefficients from a more practical point of view.

We first note that, because (3) is in ratio form and does not contain a term in the form of $1 / y$, it assumes homogeneity of degree one for consumption in $y, y e$, and $v$. This is an important point because we would be using this function for simulations lasting as long as 100 years, and even a very small deviation from homogeneity matters importantly in simulations over such a long period. We believe that this is a reasonable assumption on the basis of our survey of existing evidence, though the judgment may vary among students of the subject. We offer one more piece of evidence in support of the homogeneity which we have obtained from the data at hand.

If we introduce a term in the form of $1 / y$ into (3) and reestimate the equation, this term acquires a marginally significant positive coefficient. The question then is whether this is a genuine indication of the presence of a non-homogeneity, or it is an evidence for some biases in our estimate, for example, resulting from errors of measurement for independent variables.

To answer this question at least partially, Ando, Yamashita and Murayama (1986) estimated this equation using data from the 1974 survey and 1979 survey, and Hayashi, Ando and Ferris (1989) did the same for the 1984 survey. Coefficients of (3) remained very stable for these three surveys, while the coefficient for the term $1 / y$ increased from 1974 to 1979 and again from 1979 to 1984 more or less in proportion to the movement of the mean value of $c$. This means that $c, y, y e$, and $v$ are all increasing more or less 
proportionately from one survey to the next, indicating the long run homogeneity of a relationship like (3). We have decided to accept its homogeneous form for present purposes.

Given this decision, any biases involved in our estimates of parameters in (3) is on the distribution of the coefficient of wealth, $v$, and the coefficients of expected future income, $y$ and $y e$. While $y$ and $y e$ are separately estimated as described above, in the estimation of (3), the sum of the two coefficients for these two variables rather than each separately proved to be quite stable under minor variations of specification, so let us take them together in the assessment of their biases.

The coefficient $s$ of $v$ interacted with age dummies in (3) may be thought of as indicating the fraction of total resources (the market value of net worth plus the present value of current and future earnings) that the household wishes to consume during the current year. This proportion, of course, varies from one family to another, depending on many circumstances. The only restriction due to the homogeneity assumption discussed above is that it should not depend on the absolute level of total resources, although we do not exclude the possibility that it may depend on the relative position of the household in question in the distribution of total resources in a particular age cohort.

A careful review of the implications of a variety of environments faced by individual households indicates that, if the life cycle theory is to retain approximate validity, then the coefficient of net worth must increase with age on average, and its order of magnitude must reach the level of something like 0.10 by the time the head of the household is retired and reaches the age of 70 or so, even allowing for a fairly significant bequest motive. It can be as small as 0.01 for families the age of whose heads is in their 20 's.

Compared with this theoretical expectation, the actual estimates we have obtained for (3) using Japanese survey data for coefficients of $v$ seem somewhat too small. This 
necessarily implies that our estimates of the coefficients of $y$ and $y e$ are biased up to some extent.

This type of bias is likely to be based on one of two possible sources. First, it is possible that there is some simultaneous equations bias in our estimates of the coefficients of $y$ and $y e$, although $y$ and $y e$ used in the estimation of (3) are predictions generated by equation (2) rather than their actual values, so that the possibility of simultaneous equations bias is relatively small. Second, it may be due to error of measurement of $v$. Such errors of measurement are likely to bias the coefficient of $v$ towards zero, and given the homogeneity restriction, to bias coefficients of $y$ and ye upwards. This second possibility cannot be ruled out because we know that the measurement of $v$ is more seriously defective than the measurement of $c$ and $y$ (see Hayashi, Ando and Ferris (1989) ).

In the analysis reported here, we accept the estimates of the parameters of (3) obtained through the instrumental variable regression procedure in spite of the potential biases discussed above. In another analysis currently under way, we work with alternative estimates obtained by assuming that the observed mean consumption of a cohort is in fact the desired fraction of the total resources of the cohort in question. This alternative estimate appears to make the coefficient of net worth somewhat larger and rising with age, thus conforming to the prediction of the life cycle model more closely that the one used here.

So far, we have been concerned with the consumption behavior of active working age households 63 years old or younger. For those families with heads older than 63 years who are continuing to work, we can estimate an equation that is separate from but similar to equation (3). For those families who are remaining independent but whose heads are fully retired, we have much less information in our sample, and we assume that they will continue the behavior exhibited during the current period, namely, they tend to consume almost all of their pension receipts and a small fraction of their net worth. 
Those who are older than 63 years of age and merged into households headed by a younger individual disappear from our system as independent households. Their income, consumption, and indirectly their saving and net worth, however, enter our system through their impact on the value of dummies in equation (2) for income and in equation (3) for their consumption. The description of the process determining the critical choice of which households merge into younger households and which younger households accept older individuals is given in the next section.

\section{Dynamic Model of Demographic Development}

Equations (2) and (3) introduced in Section 3 above and similar equations for older groups generate predictions for the distribution of income and of the saving-income ratio for equation (1). In order to utilize equation (1) to work out the aggregate implications of income generation and the behavioral assumption on the saving-income ratios of cohorts of families, we must in addition have a model of demographic development that can generate the weights for each cohort. Demographic projections are quite common, and indeed, we can obtain a tape from the United Nations (1989) containing not only current demographic data but also models to generate the projection of the future development of population for all member nations.

These population projection models are, however, limited to the age and sex distribution of the population, and as far as we know, there does not exist an operational model of population dynamics which is capable of generating predictions about the distribution of family structure, such as the number and age of children in each family, the marital status of the head and the age of the spouse, presence or absence of other dependents and their sex and age. We need this additional information in order to utilize equation (1). Since this is our first attempt to model the dynamics of population, we have adopted the official model and projection for Japan provided by the Institute of Population Problems, Ministry of Health and Welfare (1992), as the shell for our more 
detailed demographic model. That is, we have adopted all of their assumptions and added some additional structure, and made sure that our projections match theirs to the extent that their projection exists, adding more details needed for our purpose.

Our starting point is the classification of all families in Japan in 1985 into cohorts, defined by age of the head, age of the spouse, and the number of children. Information required was taken from the 1985 Census and the 1984 National Survey of Family Income and Expenditure. To simplify our task, in Japan, if both husband and wife are present in the family, we designate the husband as the head. We recognize individuals as capable of being a head from the age of 19 to 79 and include in the age class 80 all individuals aged 80 and above. There are thus 62 possible age classes for the head. We find a very few families headed by persons aged less than 19 , and we simply reclassified such families as headed by 19 years old. We also recognize a female spouse to be at most 5 years older or 10 years younger than her male spouse, and when we find exceptions, we have reclassified them to eliminate them. The number of children can be zero, one, two, three, and four or more, so there are five possibilities. Thus, the number of cohorts of families headed by married couples would be potentially $(62 \times 16 \times 5)=4960$. The number of cohorts for single parent families headed by a male or female is $(62 \times 2 \times 5)=620$, and the number of cohorts of male and female single individuals is $(62 \times 2)=124$. In practice, we found no member in some marginal cohorts, and the probability that some one will move into such cohorts in the future is virtually zero, so that the total number of cohorts in our analysis turned out to be a little less than 4,000 . To each cohort is assigned a weight, representing the population size taken from Population Census of 1985 except for some details estimated from the National Survey of Family Income and Expenditure of 1984.

For each cohort, we must maintain information on the age and sex distribution of all dependents. A dependent is considered a child if he/she is aged 18 or less, otherwise such a person is considered an adult dependent, and we recognize him/her to be from age 
zero to 79 and 80 or over. Thus, we carry this set of demographic information for each cohort as 162 variables $^{8}$

In addition to demographics, each cohort must carry what may be called "semi economic" information, such as the distribution of occupation and employment status among its heads, its spouses, and among its adult dependents. Finally, one piece of economic information that must be carried by each cohort is the initial value of net worth. In this initial attempt, we have carried only the mean value of net worth for each cohort, although we recognize that it would be very useful to carry at least the second moment assuming that net worth is distributed according to, for example, the log-normal distribution.

Once the cohort structure is fully constructed for the base year, we can specify the detailed procedure for updating this structure from one year to the next. For this purpose, we found that it is best to break up the transition process for a year into several substeps and treat them as though they occur sequentially. The substeps specified are the following:

Phase 1. Death, Divorce, and Remarriage

Phase 2. Aging

Phase 3. Birth of New Children

Phase 4. New Marriage, Movement of Dependent Young Adults to Independent Status, and Retirement

Phase 5. Merger of Older Families and Individuals with Younger Families.

We briefly comment on some of these processes.

\footnotetext{
${ }^{8}$ The number of dependents in each age for a particular cohort is the average number of dependents of that age for each family in that cohort. Therefore, the number may be fractional, but when the recorded number of dependents for the cohorts are added from age zero to 18 , this sum must be equal to the number of children defining the cohort.
} 
The Institute of Population Problems (1992) provides detailed estimates of the death rate by age and sex for current and future periods, and we have simply adopted their estimates with one exception. We have reduced the birth rate and then set the death rates for those aged zero to 18 equal to zero, so that at the age 19 our projection matches the official projection in all future periods. This simplification greatly reduces computational requirements in our simulation, and it does not seem to affect our result noticeably given the very low mortality of children in Japan.

In most cases how weights among cohorts must be adjusted when someone dies is quite clear, except for one situation, namely, when a single head ( without a spouse ) of a household dies. We then must allocate dependents in this household somewhere. In this case, we have adopted an arbitrary rule by which we designate another adult in the household as the head if such an adult exists, and if not, we moved an adult whose characteristics are similar to the deceased person from a single person category to a single head of household category and assign children of the deceased to this person. The consequence of such an arbitrary rule appears to be negligible in any event because the death rate of single heads of family young enough to have child dependents is very low.

Divorce and remarriage are treated as a net process in this model ( together with consequences of death of one spouse of a married couple ), and it involves an obvious transfer of weights among cohorts. Probabilities for these events are inferred from information provided in the Final Report of the Census.

The handling of the aging process is reasonably obvious, but we wish to remind the reader that, when an 18 year old child ages one year, he is no longer a child, so that the family to which he belongs loses one child, and must move to a cohort with one less child.

As the result of the aging process, all cohorts have a value of "zero" for the position of children with age zero. Thus, newborn children can be recorded readily in all cohorts. The main complication here is that the fertility rate used in population 
projections given by the official sources is conditional only on the age of the female, while what we need is the fertility conditional on a female of a particular age being married and having had zero, one, two, three, or four or more children. In the case of Japan, as part of the discussion of the methodology of the projection, the Institute of Population Problems, (1992), provides three alternative limiting distributions of the number of children for married females associated with the three alternative fertility assumptions used in their projections. We have used these limiting distributions and calculated the implied fertility for married women of a particular age with a given number of previous births.

We then come to the description of first time marriages. What we need is the probability of marriage for an unmarried male of a specific age, and conditional on his marriage, the probability that he marries a woman of a specific age. We begin with the observed actual distribution of the marriage pattern of males in 1985 and the age distribution of their spouses, infer the probability of the male's marriage at each age conditional on his not yet being married, and modify the result in accordance with the discussion given by the Institute of Population Problems, (1992), concerning gradual shifts of the marriage age of a female in Japan over time.

We now come to the last and a more complex demographic transition pattern that is specific to the Japanese case, namely, the retirement process and merger of older families and individuals with younger families. We have indicated how widespread the practice of the merger is in Table 3. For the retirement process, we have assumed that the probability of retirement at each age and occupation remains the same in the future as it was in 1985. Since participation in the labor force is an important factor in determining the saving-income ratio for a family, a more satisfactory explanation of the retirement process is a critical refinement that should be undertaken in our future work. For the merger process, we have adopted an earlier estimate of a probit equation describing this process as a function of age, marital status, sex, and the position in the wealth distribution 
in the appropriate age group of the older individual in question, with some modification since we no longer have access to some of the variables used earlier. (Ando, Yamashita and Murayama, 1986).

In order to insure that our demographic model is generating patterns that are internally consistent, we have insured that the sum of the male (female) population of various types (married heads of households, spouses of heads, single heads of households, independent single persons, and dependents in families headed by others ) add up to the total population in each age, and that the total number of married males over all age groups is identical to the total number of married females over all age groups.

These transfers of families and individuals from one category to another inevitably involves a transfer of wealth along with persons. To describe the wealth transfer process accurately is difficult because we have no information on parents or children living away from the family in question. We have adopted the following rules:

1. If one of the spouses dies in a family in which both spouses are present, then one half of the family's net worth goes to the remaining spouse. (a) If there are one or more children living in the family ( for this purpose, any young adult living in the family whose age is appropriate is considered a potential recipient of the estate), then the remaining half goes to those children living in the family and distributed among them equally. (b) If there are no children living in the family, then one half of the estate goes to presumed children in younger cohorts. Presumed children are defined by the potential fertility of the female spouse of the family, whether she is actually present or not.

2. If a single person or single parent dies, the same process as in (1) above takes place except that the entire net worth is distributed among children or presumed children instead of one half of it.

3. When a dependent adult becomes independent, the person receives a transfer from the household in which he /she had been dependent. We set the transfer at three percent 
of the net worth of the original family if the person is 19 years old, while if the person is 20 years or older, we set the transfer equal to the average net worth of the cohort of single persons to which the newly independent person is assigned. The figure of three percent is purely arbitrary, but given the high saving rate of young single individuals in Japan, within a few years after the person becomes independent, his /her net worth is dominated by accumulated savings. The rule applying to older individuals reflects the observation that these individuals have accumulated their own net worth while living in their parents' home, but we have no way of identifying the amount.

4. When a single person living independently marries, he/she is assumed to bring his/her entire net worth into the marriage.

5. When a single person living as a dependent in the parent's family marries, he/she is presumed to be entitled to carry with him /her the same amount of net worth as the independently living single person of the same sex and age would have brought with him/her.

6. When older persons merge into younger households, they bring their entire net worth with them and add it to the net worth of the host household. Since the identity of the older person is known only as a member of a specific cohort in our simulation analysis, we do not know the exact net worth being carried by this person. We estimate the expected value of the net worth involved assuming that the relative distribution of net worth among members of the cohort remains the same from the starting point, and taking account of the probit equation for determining the probability of the merger in which the relative position of net worth among the age cohort was an independent variable.

7. The handling of inheritance and gift taxes is discussed in the next section. 


\section{Results}

We begin by looking at changes in the demographic structure of Japan between 1985 and 2050. As we have stressed earlier, our demographic model is designed to insure that the sex and age distribution of the population projection will conform to the one generated by the Institute of Population Problems, so that this aspect of our results is not new, and it is summarized in Figure A. ${ }^{9}$ The contrast between the 1985 pattern and the 2050 pattern is quite striking and almost dwarfs the differences implied by the middle and low fertility assumptions. This is especially so because, in the year 2050 , those aged 60 and above are identical under both assumptions because they had already been born before fertility assumptions deviated from each other in 1990.

Behind these simple figures are very different family structures and other patterns. We show some of these details in Table 2. As the labor force participation rate of older persons does not affect the population structure, we show only two cases, namely, the middle fertility assumption with the participation pattern remaining the same in the future as in 1985 (Table 2. B) and the case of the low fertility assumption with the participation pattern of persons 65 or older gradually declining to roughly half of what it was in 1985 . (Table 2. D). Under the middle fertility assumption, the total population reaches its peak in the year 2011 at 130.4 million, and then very slowly declines, reaching 111.5 million in 2050 and 95.7 million in 2090 . Under the low fertility assumption, on the other hand, the total population reaches its peak in the year 2006 at 127.1 million, and thereafter declines, first slowly but at an accelerating rate as time goes on. By the year 2050, it reaches 94.4 million, and by the year 2090, it reaches 61.6 million, less than half of the population in 1990.

\footnotetext{
${ }^{9}$ The Institute of Population Problems offers projections of population development under three alternative assumptions : low, middle, and high fertility. The middle fertility was supposed to have been the most likely assumption, but developments since the publication of these projections indicate that low fertility is closer to the realization. We have carried out our projections, therefore, under the middle and low fertility assumptions.
} 
Not only are these two paths very different in their aggregate population pattern over time, but their composition is also quite different. In 1985, individuals aged 19 or less constituted $29.4 \%$ of the total population, while those 70 years or older were only $4 \%$ of the total population. Under the middle fertility assumption, by the year 2025, those 19 or less are $19.3 \%$ of the total, but those 70 or more are $21.4 \%$. The pattern does not change dramatically thereafter, and in the year 2090 , they are $23.1 \%$ and $19.3 \%$, respectively. Under the low fertility assumption, for years 2025 and 2090 , those 19 or younger are $16.2 \%$ and $14.9 \%$ respectively, while those 70 or older are $22.7 \%$ and $28.8 \%$ respectively.

The birth rate in Japan has declined dramatically in recent years, and in the immediate future, even the low fertility assumption may be an overestimate of the birth rate. It is hard to believe, however, that the birth rate will remain so low for a long enough time that the population will halve in a mere 80 years (from 2010 to 2090). This would mean that the population will be declining at the rate of more than $1 \%$ per year for the most of this period. Under such a condition, we will have to reconsider our macroeconomic thinking, since most of our theory and intuition about the workings of a macroeconomy are firmly based on the notion that population grows steadily over time, however slowly or rapidly.

For analytical purposes, however, since the use of the middle fertility assumption generates an almost stationary population, it is instructive to work out the somewhat extreme case of low fertility with a steadily declining population. Hence, in the rest of this paper, we present saving and net worth patterns associated with these two fertility assumptions.

We have already discussed Table 1. A. which shows the pattern of income, saving, and net worth over a number of demographic groups in 1985. It is useful, however, to remind ourselves of several features of the behavioral patterns of some groups reported in this table. First of all, since most of the population is living in two 
parent families except for young, single persons 29 years old or less, the saving behavior of the entire population is dominated by the behavior of two parent families. The saving behavior of this group at the age above 60 is strongly affected by the fact that only relatively wealthy and economically active families remain independent, while others are merging into younger households progressively as they get older (see Table 3). The saving behavior of the middle aged group depends importantly on the number of dependents living with them - children, adult dependents, and elderly.

Second, a large number of young males are living independently and they save heavily although similar young males living with their parents save even more (Ando, Guiso, and Terlizzese, 1994a). Older male singles and male single heads of households are relatively few and they behave like two parent families. Third, young female singles earn much lower income than males, and save very little. Older female singles and female single heads of households also earn very low income, but they tend to own sizable assets, which increase with their age in spite of the fact that they by and large dissave significantly. This pattern reflects the fact that these female singles and single heads of households result from widowhood and to a lesser extent from divorce, and younger ones remarry fairly quickly, to be replaced by new widows and divorced persons. It should also be noted that, in addition to remarriage, these female single and single heads of households may be merged into the households of their parents or siblings if they are relatively poor. Thus, a mechanism somewhat similar to that applying to elderly persons operates here, leaving relatively wealthy units independent and observable, while absorbing less wealthy units into other households and therefore making them not directly observable. We believe this process is responsible for the apparent large wealth and relatively high income enjoyed by older female single heads of households shown in Table 1. A., resulting in the positive saving rate for these households. 
Alternative fertility assumptions do not deviate from each other until 1990. By the year 2000, therefore, there is little difference in the population structure under alternative fertility assumptions except that young children are more numerous under the middle fertility assumption than under the low fertility assumption. Even this difference is relatively minor compared with the decline in the number of those who are 19 years old or younger from 1985 (17.1 million) to 2000 (13.3 million under the middle fertility and 12.7 million under the low fertility assumptions). The average number of children per family correspondingly declines approximately by one-third.

It is this enormous decline in the number of children that is the primary driving force in pushing up the average saving-income ratio from 1985 (13.1\%) to 2000 (17\% for both fertility assumptions under the maintained participation rate in the work force for older persons, $15.5 \%$ for the case of the low fertility and the reduced participation rate). Effects of the reduced number of children manifest themselves primarily in the increased saving rate of young and middle aged, two parent families. The increased fraction of older persons in the population does reduce the saving-income rate, both through the higher weight given to older families and through the larger presence of older dependents in middle aged families, but at this stage of demographic development, the reduced number of children is much more important.

After the year 2000, the aggregate saving-income ratio declines gradually as the population ages. This is especially noticeable for the low fertility, reduced participation case, in which the over-all saving-income ratio declines to $12.5 \%$ in year $2025,8.5 \%$ in 2050, and $7.8 \%$ in year 2090. (Table 1. D. 1 to 1 . D. 4). The saving-income ratio is reduced less if the participation rate is not reduced (Tables 1. C. 1 to 1. C. 4) and if somewhat higher fertility is maintained (Tables 1. B. 1 to 1. B. 3). Even this declining saving-income ratio implies a much higher net worth-income ratio than that observed in 1985 given the reduced growth rate of the population. 
Under the low fertility assumption, as we have noted earlier, the population is declining steadily at about $1 \%$ per year. The working age population is declining at a somewhat faster rate until about the year 2040 , and at $1 \%$ per year thereafter. Since we assume a steady productivity increase per worker of $2 \%$ per year, this decline in the work force implies that aggregate output is increasing at $1 \%$ per year if the full utilization of resources could be maintained ${ }^{10}$. The well known accounting identity requires that, on a steady state growth path, the saving-income ratio must be equal to the rate of growth of income times the ratio of net worth to income. Therefore, the rate of growth of aggregate income of $1 \%$ together with the saving-income ratio of $8 \%$ implies a net worth-income ratio of something close to 8 . This is what we observe for year 2090 in Table 1. D. 4., in contrast to the net worth-income ratio of about 5 in 1985. Such a high level of the net worth-income ratio has never been observed for any country, forcing us to review our assumptions underlying the simulation result reported here.

First, we may question the demographic assumptions, as we have never observed such a rapid decline in population taking place in a developed society of the world. It may be that the decline of the population produced by the demographic model and its underlying assumptions are plausible, but then such a demographic condition is so far different from the recent experiences of economically advanced societies that our basic theory of savings behavior may no longer apply. These are questions that may be debated, but we do not believe that we can resolve them empirically with existing data.

Second, a major issue specific to Japan is the role of the extraordinarily high value of land, which is, of course, a non- reproducible asset and therefore its aggregate value does not depend on savings behavior directly. It is possible to visualize a situation in which the relative price of land is so high that many families are squeezed into a very small living space, say 50 to 100 square meters, because even such a small space is worth

\footnotetext{
${ }^{10}$ See our discussion below on the question of the Keynesian disequilibrium.
} 
hundreds of thousands of dollars and hence it is the maximum affordable for families with average earnings. In that case, is it not possible that the desired total net worthincome ratio including the value of space (either the direct ownership of land or an indirect ownership through the ownership of an apartment) is much higher than that in the case in which the relative price of land is an order of magnitude smaller, even though the implied equilibrium ratio between net worth excluding the value of space to income is significantly smaller for the high land price case than the low land price one? Furthermore, as the population declines, should we not allow for the possibility that the relative price of land will decline significantly due to the declining demand for living space, thus necessitating a higher saving-income ratio to maintain the equilibrium net worth-income ratio at a reasonable level? These are questions which are especially critical for Japan, and for which we do not yet have satisfactory answers either theoretically or empirically.

Third, in our simulations we have assumed that the rate of growth of productivity is independent of the saving-income ratio and the rate of accumulation of capital. One may entertain an argument that the higher accumulation of capital may lead to the higher rate of increase of productivity for several reasons, at least in the intermediate run. It is possible that the higher capital-output ratio by itself would imply higher productivity per worker, although this possibility is not very plausible. The reason is that in most advanced economies, the capital-output ratio appears to be already near that characterized by the so-called golden rule, so that increasing the capital-output ratio further would lead to a higher level of gross output and a larger depreciation per unit of output but not to a higher level of net output and consumption (See, for example, Anderson, Ando and Enzler, 1984). But this process does imply higher turn-over of capital, and therefore, in a vintage capital model, may imply a faster adaptation of newer technology and hence larger output. We do not believe that this process can have a quantitatively important effect. The limiting case is the model of fully malleable capital which can be analytically 
analyzed, and we do not see that it makes a really significant difference between the malleable case and the vintage capital case on an equilibrium path, although the differences in short-run response between two cases are very important. Finally, a number of processes recently explored under the heading of endogenous growth models may lead to a causal chain from the higher saving rate to the higher rate of growth of aggregate productivity per worker, but the full exploration of these possibilities is at the moment beyond the scope of this paper.

The fourth issue is the potential biases of our estimates of the parameters of the consumption function and their consistency or conflict with the strict implications of the life cycle theory. Our consumption functions for various groups when they are substituted into equation (1), given the demographic structure, would imply an approximate aggregate equation of the form

$$
C_{t}=a_{Y} Y_{t}+a_{A} A_{t-1}
$$

where $C_{t}, Y_{t}$, and $A_{t-1}$ are national aggregates of consumption, disposable income and the initial value of net worth, respectively, for period t, and $a_{Y}$ and $a_{A}$ are parameters. These parameters are in principle functions of many things except the absolute levels of $Y$ and $A$, but most importantly, $a_{A}$ is, according to the life cycle theory, a function of the rate of growth of $Y$ and the higher the rate of growth of $Y$ the lower the value of $a_{A}$. Writing $a_{A}(g)$ where $g$ represents the rate of growth of $Y$, we know that the equilibrium value of the net-worth income ratio is given by ${ }^{11}$

\footnotetext{
${ }^{11}$ This assumes that any real capital gains in $\mathrm{A}$ is included in saving, so that

$$
\begin{aligned}
A_{t}-A_{t-1} & =S_{t}=Y_{t}-C_{t} \\
& =\left(1-a_{Y}\right) Y_{t}-a_{A}(g) A_{t-1}
\end{aligned}
$$
}




$$
\frac{A}{Y}=\frac{1-a_{Y}}{a_{A}(g)+g}
$$

(5) implies that the equilibrium value of $A / Y$ is a strongly negative function of $g$ unless $a_{A}(g)$ has a derivative with respect to $g$ close to unity. While we believe that the derivative of $a_{A}(g)$ with respect to $g$ should be close to unity on a theoretical basis, our empirical estimates used in the simulation makes it a much weaker function of $\mathrm{g}$, and we believe that this is where the most serious estimation bias may be found. ${ }^{12}$ Given the available data, however, it is virtually impossible to explore the extent of this bias empirically unless we impose a stronger structure on our behavioral model before the estimation. In a future paper, we propose to investigate this question through an alternative model with a more rigid a priori structure.

The second source of potentially important bias is the lack of dynamics in our consumption functions. In Table 5. C., we have given a strong suggestion that habit persistence may be quite important in the consumption behavior in Japan, and this may lead to a possible reduction in the saving-income ratio as the rate of growth of income declines. We believe, however, that this is still an open question which requires extensive additional data and analysis before it can be settled with any confidence.

$$
\frac{A_{t}-A_{t-1}}{A_{t-1}}=g+\left(1-a_{Y}\right)\left[\frac{Y_{t}}{A_{t-1}}-\frac{a_{A}(g)+g}{1-a_{Y}}\right]
$$

Since, on an equilibrium path, the requirement that $\mathrm{A} / \mathrm{Y}$ must be constant implies that the rate of growth of $A$ must be equal to the rate of growth of $Y$, equation (5) results immediately from the above.

${ }^{12}$ Given the homogeneity property of the consumption function used and its implication that the aggregate relation (4) is also homogenous in $\mathrm{Y}$ and $\mathrm{A}$, we can readily see that given a set of data an increase in the value of $a_{A}$ given $g$ must be compensated by a reduction in the value of $a_{Y}$ in order to fit the data. We can see, in turn, from (5) that such a trade-off would not change the equilibrium value of $\mathrm{A} / \mathrm{Y}$ a great deal. Thus, the issue here is not the value of $a_{A}$ given $g$ but the response of $a_{A}$ to changes in $\mathrm{g}$. 
The third potential bias is the role of inheritance taxes which we have ignored in our main simulation analysis but we have explored to some extent. According to the Annual Statistical Report of the National Tax Office of the Japanese Government, the average effective rate of inheritance and gift taxes on assets reported to be transferred from one generation to the next is roughly 18 percent. Assets reported to be transferred must be much smaller than assets actually transferred, partly because the value of land transferred, which is more than 67.5 percent of total assets reported to be transferred, is radically underestimated for this purpose, and partly because a significant portion of net worth is exempt from inheritance and gift taxes. In most of our simulation analysis, we have ignored this question, but we have made one simulation in which we assumed that all intergenerational transfers were subjected to the transfer tax of 18 percent in order to see the maximum possible effect of this on net worth accumulation. The difference between these two alternative simulations was only 7.7 against 7.9 for the net worthincome ratio for all households in 2050 , although the difference tended to be concentrated in younger cohorts so that the effects on them were a little larger. We believe, therefore, that the effect of ignoring this tax was not negligible but it is not a major one.

The fifth and the last issue is the macro stabilization implications of the results reported here and possible government responses. If the saving-income ratio in Japan remains as high as our results suggest in the face of declining population and if we are correct in believing that the capital-output ratio in Japan is already close to the golden rule level from the point of view of production efficiency, the Japanese economy may be increasingly subject to the classical Keynesian imbalances between saving and investment demand, that is, if all saving forthcoming at the full employment condition is invested in additional productive capital, the marginal product of capital may become very low or even negative because the maintainable value of consumption is actually reduced by having to keep up the excessive level of capital. This would clearly lead to the situation where insufficient final demand would create serious unemployment problems unless a 
significant amount of saving is diverted to additional current account surplus, or government fiscal policies can be designed to restore the necessary balance. While these are issues that require another major investigation to gain full understanding of their features and implications, it is important that we note it here explicitly because they are in the opposite direction from the popular formulation of the major policy issues in Japan and elsewhere: namely, that the decline in the birth rate and consequent aging of population may result in serious shortages of output to satisfy the consumption needs of the population while providing for adequate maintenance of the capital stock.

$\dot{W}$ e began this paper by noting that the balancing of the need of a society for capital accumulation and the saving generated by the society is an essential condition for an orderly development of the economy in the society. We have analyzed the consequences of some radical shifts in demographic patterns that Japan is apparently facing during the next several decades, and tentatively concluded that Japan is more likely to be faced with an excess saving condition rather than a shortage of saving. This conclusion may be overturned if it can be shown that our estimate of the effects of the growth rate of income on the coefficient of net worth in the consumption function is seriously biased toward zero, or we have badly underestimated the impact of the saving rate on productivity growth discussed in the recent literature on endogenous growth. We believe that neither of these possibilities can be fully excluded, although they are not very likely to be strong enough to overturn our tentative conclusions. In any case, these are important questions that must be investigated seriously.

In the meanwhile, we believe that the analytical apparatus that we have developed here, especially the aggregation process embodied in equation (1) and the detailed model of the demographic dynamics described in Section 4 of this paper, is capable of accommodating a wide variety of theoretical structures concerning household behavior and should prove useful for analyzing the aggregate implications of not only alternative 
micro hypotheses of saving behavior but of other aspects of consumer behavior such as their demand for specific goods and services, such as medical services.

Furthermore, our apparatus is well suited to study the consequences of an intergenerational redistribution of resources due, for example, to a revision of social security provisions.

On the other hand, we have not yet explored the effects of economic conditions faced by families on the dynamics of demography, and the dynamic characteristics of the system in which the simultaneous presence of causality from demographics to economic conditions and the one from economic conditions to demographics is recognized. This is a major subject for which an analysis such as the one presented here is a necessary preliminary inquiry. In the present study, we have also de-emphasized issues associated with income and asset distribution within cohorts, in order to keep our technical problems within manageable proportions. We believe, however, it is feasible to incorporate such distributional issues into our analysis under an assumption that the income distribution within cohorts follows a specific algebraic pattern, such as the lognormal or Pareto distributions. These are major questions that future work using the framework outlined here should yield fruitful results.

\section{References:}

Anderson, R., A. Ando, and J. Enzler, "Long-run Effects of Alternative Fiscal Policies", American Economic Review, May, 1984

Ando, A., L. Guiso, and D. Terlizzese (1994a). "Young Households' Saving and the Life Cycle of Opportunities. Evidence from Japan and Italy", in A. Ando et. al., Eds. Saving and the Accumulation of Wealth, Cambridge, UK and New York, NY, Cambridge University Press. 
Ando, A., L. Guiso, and D. Terlizzese (1994b). "Dissaving by The Elderly, Transfer Motives, and Liquidity Constraints", in A. Ando et. al., Eds., Saving and the Accumulation of Wealth, Cambridge, UK and New York, NY, Cambridge University Press.

Ando, A., M. Yamashita, and J. Murayama (1986). "Analysis of Consumption and Saving based on National Survey of Family Income and Expenditure", Economic Analysis, 101, Tokyo, Japan, Economic Research Institute, Economic Planning Agency (in Japanese).

Ando, A., A. Moro, J. P. Cordoba, and G. Garland, Dynamics of Demographic Development and Its Impact on Personal Saving: Case of Japan", Richerche Economiche, September, 1995.

Bosworth, B., G. Burtless, and J. Sabelhaus (1991). "The Decline in Saving: Evidence from Household Surveys", Brookings Papers on Economic Activity 1, 183-256.

Cannari, L. (1994). "Do Demographic Changes Explain the Decline in the Saving Rate of Italian Households?", in A. Ando et. al., Eds., Saving and the Accumulation of Wealth, Cambridge, UK and New York, NY, Cambridge University Press.

Gokhale, J., L. Kotlikoff, and J. Sabelhaus (1994). "Understanding the Postwar Decline in United States Saving: a Cohort Analysis”. Mimeo.

Hayashi, F., A. Ando, and R. Ferris (1989). "Life Cycle and Bequest Savings" in Saving Behavior, Investment, and Rate of Return on Capital in the US. and Japan: Comparative Analysis and Perspectives into 1990's, Tokyo, National Institute for Research Advancement.

Institute of Population Problems, Ministry of Health and Welfare (1992). Population Projections for Japan: 1991-2090, Research Series No. 271. Tokyo, Japan, Ministry of Health and Welfare (in Japanese).

Kirman, A. (1992). "Whom or What Does the Representative Individual Represent?" The Journal of Economic Perspectives, Vol 6, No. 2, pp. 117-136.

Modigliani, F., and R. Brumberg (1980). "Utility Analysis and Aggregate Consumption Functions: An Attempt at Integration" in A. Abel, (ed.) The Collected Papers of Franco Modigliani, Cambridge, MA. MIT Press, Vol. II.

National Tax Office, Government of Japan (1986). Annual Statistical Report, 1984. Tokyo, Japan.

Statistics Bureau, Management and Coordination Agency, Government of Japan (1987). 1984 National Survey of Family Income and Expenditure, Tokyo, Japan. 
Statistics Bureau, Management and Coordination Agency, Government of Japan (1990). Final Report of the 1985 Population Census: Population of Japan (Statistical Tables), Tokyo, Japan.

United Nations, (1989). Global Estimates and Projections of Population by Sex and Age, the 1988 Revision, New York. 


\section{Appendix 1:Family types and Saving Rates USA*}

Part 1

\begin{tabular}{|l|l|l|l|l|l|}
\hline & 1960 & $1972-72$ & $1984-85$ & $1986-87$ & $1988-90$ \\
\hline Saving Rate & & & & & \\
\hline All Families & & & $3.47 \%$ & $4.20 \%$ & $5.86 \%$ \\
\hline Single parent & & & $-12.56 \%$ & $-12.36 \%$ & $-9.67 \%$ \\
\hline Single & & & $-3.12 \%$ & $-7.48 \%$ & $-6.10 \%$ \\
\hline Nuclear & & & $6.76 \%$ & $9.15 \%$ & $10.55 \%$ \\
\hline Extended & & & $5.64 \%$ & $7.57 \%$ & $8.52 \%$ \\
\hline
\end{tabular}

\section{Part 2}

\begin{tabular}{|l|l|l|l|l|l|}
\hline & 1960 & $1972-72$ & $1984-85$ & $1986-87$ & $1988-90$ \\
\hline Household Distribution & & & & & \\
\hline All Families & $100.00 \%$ & $100.00 \%$ & $100.00 \%$ & $100.00 \%$ & $100.00 \%$ \\
\hline Single Parent & $3.34 \%$ & $5.93 \%$ & $11.59 \%$ & $12.19 \%$ & $12.20 \%$ \\
\hline Single & $15.05 \%$ & $22.11 \%$ & $27.25 \%$ & $28.86 \%$ & $28.57 \%$ \\
\hline Nuclear & $81.61 \%$ & $60.33 \%$ & $46.54 \%$ & $45.53 \%$ & $45.18 \%$ \\
\hline Extended & & $11.63 \%$ & $14.62 \%$ & $13.42 \%$ & $14.05 \%$ \\
\hline & & & & & \\
\hline
\end{tabular}

\section{Part 3}

\begin{tabular}{|c|c|c|c|c|c|}
\hline & 1960 & $1972-72$ & $1984-85$ & $1986-87$ & $1988-90$ \\
\hline $\begin{array}{l}\text { Relative Disposable Income } \\
\text { All Families }\end{array}$ & & & 100.0 & 100.0 & 100.0 \\
\hline Single Parent & & & 67.5 & 62.9 & 65.8 \\
\hline Single & & & 57.7 & 54.2 & 57.5 \\
\hline Nuclear & & & 121.2 & 119.3 & 124.6 \\
\hline Extended & & & 137.0 & 132.7 & 137.1 \\
\hline
\end{tabular}

\section{Part 4}

Estimate of Aggregate Saving Rate for 1980's Using 1960 and 1972-73

Weights of Family Types

\begin{tabular}{|l|l|l|l|l|l|}
\hline & $(1)$ & $(2)$ & $(3)$ & $(4)$ & $(5)$ \\
\hline & Actual & $1960^{\prime}$ Weight & $\begin{array}{l}1972-73 \\
\text { Weights }\end{array}$ & $(2) /(1)$ & $(3) /(1)$ \\
\hline $1984-85$ & $3.47 \%$ & $6.07 \%$ & $4.94 \%$ & 1.75 & 1.42 \\
\hline $1986-87$ & $4.20 \%$ & $7.91 \%$ & $6.40 \%$ & 1.88 & 1.52 \\
\hline $1988-90$ & $5.86 \%$ & $9.82 \%$ & $8.18 \%$. & 1.68 & 1.40 \\
\hline
\end{tabular}

This appendix was prepared from the Public Use Tapes of Survey of Consumer Expenditure, Bureau of Labor Statistics.

Income and Expenditure for these calculations are defined to make them as close as possible to the definition used in National Income and Product Accounts. The resulting estimates, however, still contain significant conceptual differences from the NIPA accounts; the most important diffence is that saving here

* Results reported in this appendix are due to Juan Pablo Cordoba. See Ando, Moro, Cordoba and Garland (1995). 
does not include employer contributions to private pension funds. Top-coded entries are adjusted by our estimates of their actual values.

Part I of the table gives the saving-income ratio for various family types in the 1980's, and Part III gives the relative size of income for the same groups. Part II provides the relative size of these groups for the 1980's as well as for 1960 and 1972-73, the earlier years for which the same survey results are available. We can then ask the question: assuming that the saving-income rate for these groups and the relative size of income were the same for earlier years as for the 1980's, does the shift of weights among these groups explain a significant portion of the change in the aggregate saving-income ratio from 1960 to the 1980 's? To answer this question, we recompute the aggregate saving-income ratio taking the group ratio and relative income positions in the1980's as given but using relative weights for 1960 and 1972-73. The results are given in part IV. We find that a significant part of the decline in the aggregate saving-income ratio is indeed explained by shifts in weights among these groups. 
Table 1.A

\section{Saving-Income and Net Worth-Income-Ratios for Detailed Demographic Groups 1985 (Actual)}

\begin{tabular}{|c|c|c|c|c|}
\hline Category & Weight & Income & Sav/Inc & Ass/lnc \\
\hline All people & 38318998 & 453 & 0.131 & 5.274 \\
\hline Families, totals & 28001322 & 524 & 0.128 & 5.665 \\
\hline $\begin{array}{c}\text { Families, by age groups: } \\
\qquad=29 \\
30-39 \\
4-49 \\
50-59 \\
60-69 \\
>=70 \\
\end{array}$ & $\begin{array}{l}1587121 \\
7647673 \\
7974612 \\
6222498 \\
3316032 \\
1253385 \\
\end{array}$ & $\begin{array}{l}316 \\
455 \\
569 \\
629 \\
516 \\
404 \\
\end{array}$ & $\begin{array}{l}0.041 \\
0.108 \\
0.119 \\
0.136 \\
0.176 \\
0.194 \\
\end{array}$ & $\begin{array}{l}2.201 \\
4.361 \\
5.294 \\
6.276 \\
8.053 \\
8.610 \\
\end{array}$ \\
\hline $\begin{array}{c}\text { Single head of household, by sex } \\
\text { Males } \\
\text { Females } \\
\end{array}$ & $\begin{array}{r}457418 \\
1109434 \\
\end{array}$ & $\begin{array}{l}468 \\
343 \\
\end{array}$ & $\begin{array}{r}0.154 \\
-0.076 \\
\end{array}$ & $\begin{array}{l}6.747 \\
6.606 \\
\end{array}$ \\
\hline $\begin{array}{c}\text { Single head of household, } \\
\text { by sex and age groups } \\
\text { Males, }<=29 \\
30-39 \\
40-49 \\
50-59 \\
60-69 \\
>=70 \\
\end{array}$ & $\begin{array}{r}75554 \\
144523 \\
52620 \\
63517 \\
54144 \\
67061 \\
\end{array}$ & $\begin{array}{l}334 \\
456 \\
534 \\
595 \\
516 \\
433 \\
\end{array}$ & $\begin{array}{r}-0.061 \\
0.144 \\
0.194 \\
0.225 \\
0.248 \\
0.137 \\
\end{array}$ & $\begin{array}{r}6.337 \\
5.732 \\
5.747 \\
6.611 \\
6.829 \\
10.471 \\
\end{array}$ \\
\hline $\begin{array}{c}\text { Females, }<=29 \\
30-39 \\
40-49 \\
50-59 \\
60-69 \\
>=70 \\
\end{array}$ & $\begin{array}{r}34750 \\
164222 \\
319567 \\
300820 \\
213451 \\
76624 \\
\end{array}$ & $\begin{array}{l}206 \\
253 \\
344 \\
375 \\
382 \\
354 \\
\end{array}$ & $\begin{array}{r}-0.185 \\
-0.134 \\
-0.101 \\
-0.149 \\
0.025 \\
0.148 \\
\end{array}$ & $\begin{array}{l}3.082 \\
4.117 \\
5.215 \\
7.311 \\
8.350 \\
8.820 \\
\end{array}$ \\
\hline $\begin{array}{c}\text { Single, by sex } \\
\text { Males } \\
\text { Females } \\
\end{array}$ & $\begin{array}{l}4898274 \\
3852550 \\
\end{array}$ & $\begin{array}{l}297 \\
164 \\
\end{array}$ & $\begin{array}{r}0.276 \\
-0.018 \\
\end{array}$ & $\begin{array}{l}1.660 \\
3.211 \\
\end{array}$ \\
\hline $\begin{array}{c}\text { Singles, } \\
\text { by sex and age groups } \\
\text { Males, }<=29 \\
30-39 \\
40-49 \\
50-59 \\
60-69 \\
>=70 \\
\end{array}$ & $\begin{array}{r}3473326 \\
757023 \\
229651 \\
192884 \\
114622 \\
130769 \\
\end{array}$ & $\begin{array}{l}259 \\
398 \\
476 \\
483 \\
280 \\
163\end{array}$ & $\begin{array}{l}0.218 \\
0.370 \\
0.415 \\
0.421 \\
0.303 \\
0.005\end{array}$ & $\begin{array}{l}1.252 \\
1.806 \\
2.329 \\
2.925 \\
3.667 \\
4.847\end{array}$ \\
\hline $\begin{array}{c}\text { Females, }<=29 \\
30-39 \\
40-49 \\
50-59 \\
60-69 \\
>=70\end{array}$ & $\begin{array}{r}1771643 \\
209050 \\
191133 \\
439030 \\
741567 \\
500125 \\
\end{array}$ & $\begin{array}{l}155 \\
183 \\
192 \\
187 \\
167 \\
154 \\
\end{array}$ & $\begin{array}{r}0.028 \\
0.031 \\
-0.032 \\
-0.062 \\
-0.075 \\
-0.061 \\
\end{array}$ & $\begin{array}{l}0.977 \\
2.220 \\
3.961 \\
4.708 \\
5.866 \\
5.432 \\
\end{array}$ \\
\hline
\end{tabular}


Table 1.B.1

Saving-Income and Net Worth-Income-Ratios for Detailed Demographic Groups

Middle Fertility-Normal Participation Rate, Year 2000

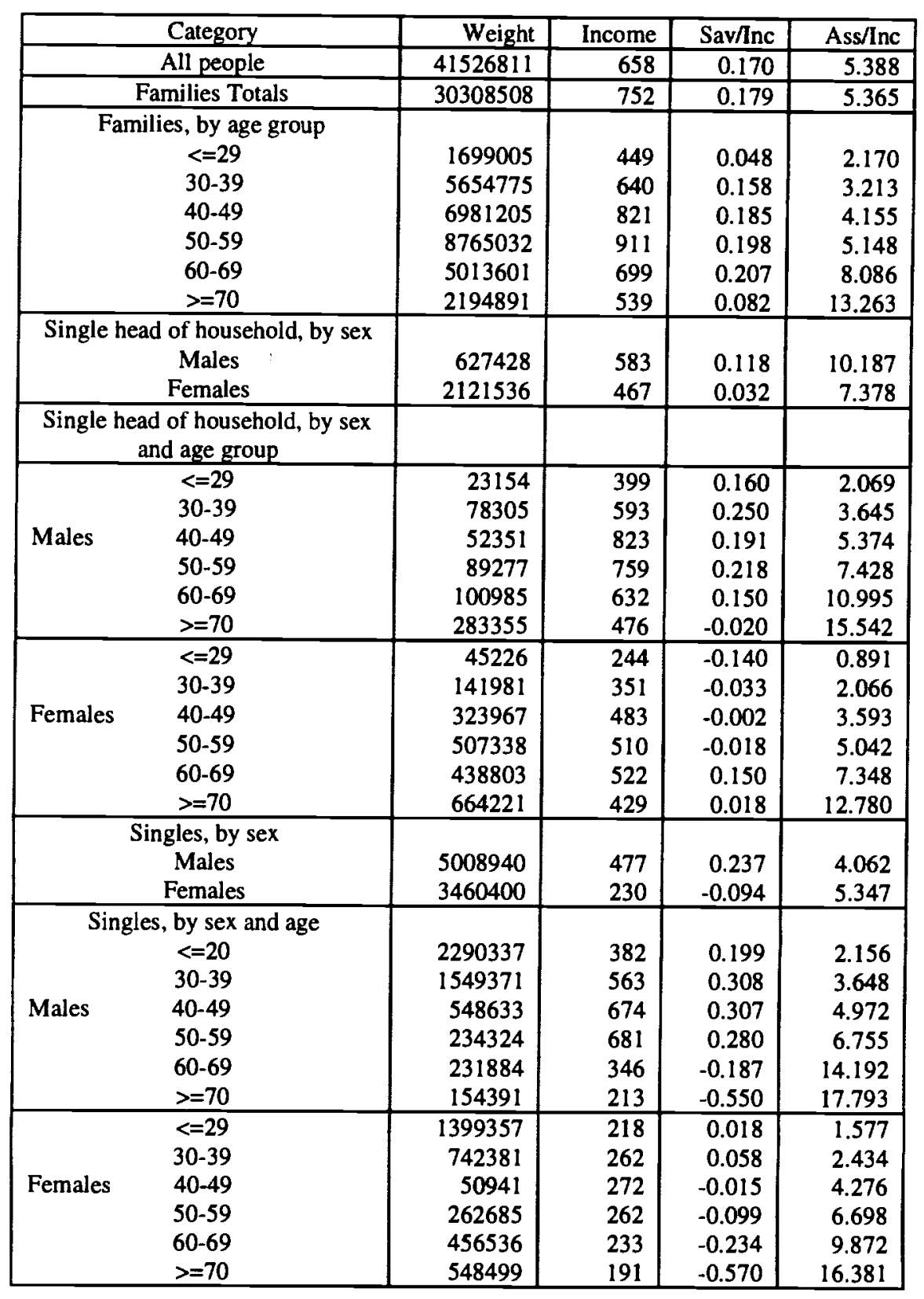


Table 1.B.2

\section{Saving-Income and Net Worth-Income-Ratios for Detailed Demographic Groups}

Middle Fertility-Normal Participation Rate, Year 2025

\begin{tabular}{|c|c|c|c|c|}
\hline Category & Weight & Income & Sav/Inc & Ass/Inc \\
\hline All people & 38275556 & 1071 & 0.146 & 6.861 \\
\hline Families Totals & 27550827 & 1221 & 0.163 & 6.444 \\
\hline $\begin{array}{c}\text { Families, by age group } \\
\qquad=29 \\
30-39 \\
40-49 \\
50-59 \\
60-69 \\
>=70 \\
\end{array}$ & $\begin{array}{l}1094259 \\
3975463 \\
6296270 \\
7651380 \\
5158694 \\
3374761 \\
\end{array}$ & $\begin{array}{r}737 \\
1055 \\
1338 \\
1492 \\
1156 \\
847 \\
\end{array}$ & $\begin{array}{l}0.004 \\
0.104 \\
0.140 \\
0.196 \\
0.231 \\
0.084\end{array}$ & $\begin{array}{r}3.476 \\
5.013 \\
5.313 \\
5.380 \\
7.681 \\
14.315 \\
\end{array}$ \\
\hline $\begin{array}{c}\text { Singles, head of household, by sex } \\
\text { Males } \\
\text { Females }\end{array}$ & $\begin{array}{r}772074 \\
2728878 \\
\end{array}$ & $\begin{array}{l}900 \\
755 \\
\end{array}$ & $\begin{array}{l}0.080 \\
0.023 \\
\end{array}$ & $\begin{array}{l}13.956 \\
11.121 \\
\end{array}$ \\
\hline $\begin{array}{c}\text { Singles, head of household by sex } \\
\text { and age groups } \\
<=29 \\
30-39 \\
\text { Males } \quad 40-49 \\
50-59 \\
60-69 \\
>=70 \\
\end{array}$ & $\begin{array}{r}14333 \\
54546 \\
48223 \\
98561 \\
114639 \\
441772 \\
\end{array}$ & $\begin{array}{r}655 \\
952 \\
1281 \\
1250 \\
1047 \\
743 \\
\end{array}$ & $\begin{array}{r}0.128 \\
0.234 \\
0.222 \\
0.246 \\
0.205 \\
-0.081 \\
\end{array}$ & $\begin{array}{r}3.144 \\
4.737 \\
5.703 \\
7.282 \\
9.945 \\
21.249 \\
\end{array}$ \\
\hline $\begin{array}{l}<=29 \\
30-39 \\
40-49 \\
50-59 \\
60-69 \\
>=70\end{array}$ & $\begin{array}{r}29581 \\
101714 \\
268526 \\
492984 \\
508630 \\
1327443 \\
\end{array}$ & $\begin{array}{l}402 \\
582 \\
810 \\
838 \\
855 \\
695 \\
\end{array}$ & $\begin{array}{r}-0.190 \\
-0.080 \\
-0.010 \\
0.032 \\
0.182 \\
-0.039 \\
\end{array}$ & $\begin{array}{r}.202 \\
3.575 \\
4.046 \\
4.247 \\
7.324 \\
18.256 \\
\end{array}$ \\
\hline $\begin{array}{l}\text { Singles, by sex } \\
\text { Males } \\
\text { Females }\end{array}$ & $\begin{array}{l}4470813 \\
2717385\end{array}$ & $\begin{array}{l}787 \\
378\end{array}$ & $\begin{array}{r}0.158 \\
-0.164\end{array}$ & $\begin{array}{l}6.776 \\
7.523\end{array}$ \\
\hline 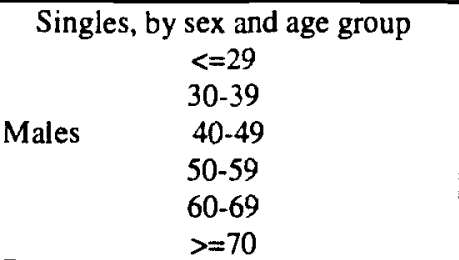 & $\begin{array}{r}1617930 \\
859878 \\
569206 \\
583038 \\
485553 \\
355207\end{array}$ & $\begin{array}{r}623 \\
924 \\
1104 \\
1118 \\
642 \\
345\end{array}$ & $\begin{array}{r}0.172 \\
0.269 \\
0.251 \\
0.251 \\
-0.167 \\
-0.831\end{array}$ & $\begin{array}{r}2.884 \\
4.909 \\
6.460 \\
7.780 \\
15.253 \\
25.627\end{array}$ \\
\hline $\begin{array}{l}<=29 \\
30-39 \\
40-49 \\
50-59 \\
60-69 \\
>=70\end{array}$ & $\begin{array}{r}1045858 \\
331038 \\
139108 \\
370497 \\
337614 \\
493270\end{array}$ & $\begin{array}{l}360 \\
439 \\
446 \\
434 \\
392 \\
303\end{array}$ & $\begin{array}{l}-0.027 \\
-0.031 \\
-0.092 \\
-0.053 \\
-0.161 \\
-0.790\end{array}$ & $\begin{array}{r}2.682 \\
5.159 \\
6.394 \\
6.377 \\
9.024 \\
22.370\end{array}$ \\
\hline
\end{tabular}


Table 1.B.3

\section{Saving-Income and Net Worth-Income-Ratios for Detailed Demographic Groups}

Middle Fertility-Normal Participation Rate, 2050

\begin{tabular}{|c|c|c|c|c|}
\hline CATEGORY & WEIGHT & INCOME & SAV/INC & ASS/INC \\
\hline All people & 32568273 & 1695 & 0.119 & 7.980 \\
\hline Families Totals & 22788071 & 1953 & 0.141 & 7.264 \\
\hline $\begin{array}{c}\text { Families, by age groups } \\
<=29 \\
30-39 \\
40-49 \\
40-49 \\
50-59 \\
>=70 \\
\end{array}$ & $\begin{array}{r}880534 \\
3833922 \\
5592336 \\
4865025 \\
4310379 \\
3305874 \\
\end{array}$ & $\begin{array}{l}1211 \\
1738 \\
2208 \\
2451 \\
1861 \\
1358 \\
\end{array}$ & $\begin{array}{r}-0.012 \\
0.097 \\
0.122 \\
0.161 \\
0.223 \\
0.095 \\
\end{array}$ & $\begin{array}{r}3.945 \\
5.289 \\
5.774 \\
6.386 \\
8.777 \\
14.713 \\
\end{array}$ \\
\hline $\begin{array}{c}\begin{array}{c}\text { Single head of household, by sex } \\
\text { Males } \\
\text { Females }\end{array} \\
\end{array}$ & $\begin{array}{r}858027 \\
2718902 \\
\end{array}$ & $\begin{array}{r}1403 \\
1208 \\
\end{array}$ & $\begin{array}{r}0.044 \\
-0.004 \\
\end{array}$ & $\begin{array}{l}17.098 \\
14.363 \\
\end{array}$ \\
\hline $\begin{array}{l}\text { Single head of household, by sex } \\
\text { and age groups }\end{array}$ & & & & \\
\hline $\begin{array}{l}<=29 \\
30-39 \\
40-49 \\
50-59 \\
60-69 \\
>=70 \\
\end{array}$ & $\begin{array}{r}11870 \\
52448 \\
43022 \\
62941 \\
111748 \\
575998 \\
\end{array}$ & $\begin{array}{l}1077 \\
1570 \\
2104 \\
2061 \\
1689 \\
1215 \\
\end{array}$ & $\begin{array}{r}0.112 \\
0.226 \\
0.209 \\
0.209 \\
0.202 \\
-0.073 \\
\end{array}$ & $\begin{array}{r}3.582 \\
5.062 \\
6.131 \\
8.389 \\
10.901 \\
23.467 \\
\end{array}$ \\
\hline $\begin{array}{l}<=29 \\
30-39 \\
40-49 \\
50-59 \\
60-69 \\
>=70 \\
\end{array}$ & $\begin{array}{r}23663 \\
98065 \\
235704 \\
316720 \\
450536 \\
1594213 \\
\end{array}$ & $\begin{array}{r}663 \\
963 \\
1333 \\
1382 \\
1417 \\
1120 \\
\end{array}$ & $\begin{array}{r}-0.212 \\
-0.091 \\
-0.028 \\
-0.033 \\
0.193 \\
-0.056 \\
\end{array}$ & $\begin{array}{r}2.791 \\
4.077 \\
4.593 \\
6.064 \\
7.607 \\
21.180 \\
\end{array}$ \\
\hline $\begin{array}{c}\text { Singles, by sex } \\
\text { Males } \\
\text { Females } \\
\end{array}$ & $\begin{array}{l}3778530 \\
2424743 \\
\end{array}$ & $\begin{array}{r}1248 \\
611 \\
\end{array}$ & $\begin{array}{r}0.120 \\
-0.217 \\
\end{array}$ & $\begin{array}{l}7.645 \\
8.985 \\
\end{array}$ \\
\hline \begin{tabular}{cc}
\multicolumn{2}{c}{ Singles, by sex and age group } \\
\\
& $<=29$ \\
Males & $30-39$ \\
& $40-49$ \\
& $50-59$ \\
& $60-69$ \\
& $>=70$ \\
\end{tabular} & $\begin{array}{r}1255612 \\
821965 \\
509586 \\
356801 \\
343779 \\
490787 \\
\end{array}$ & $\begin{array}{r}1024 \\
1516 \\
1812 \\
1835 \\
960 \\
562 \\
\end{array}$ & $\begin{array}{r}0.160 \\
0.266 \\
0.240 \\
0.215 \\
-0.272 \\
-0.879 \\
\end{array}$ & $\begin{array}{r}3.234 \\
5.113 \\
6.835 \\
8.838 \\
17.511 \\
27.718 \\
\end{array}$ \\
\hline $\begin{array}{l}<=29 \\
30-39 \\
40-49 \\
50-59 \\
60-69 \\
>=70\end{array}$ & $\begin{array}{l}787459 \\
318831 \\
227922 \\
200856 \\
239396 \\
650278 \\
\end{array}$ & $\begin{array}{l}590 \\
712 \\
731 \\
717 \\
626 \\
506 \\
\end{array}$ & $\begin{array}{l}-0.043 \\
-0.041 \\
-0.112 \\
-0.163 \\
-0.321 \\
-0.614 \\
\end{array}$ & $\begin{array}{r}3.189 \\
5.608 \\
7.175 \\
9.503 \\
12.950 \\
18.370\end{array}$ \\
\hline
\end{tabular}


Table 1.C.1

Saving-Income and Net Worth-Income-Ratios for Detailed Demographic Groups

Low Fertility-Normal Participation Rate, Year 2000

\begin{tabular}{|c|c|c|c|c|}
\hline Category & WEIGHT & INCOME & SAV/NC & ASS/INC \\
\hline All People & 41527432 & 658 & 0.170 & 5.388 \\
\hline Families Totals & 30308884 & 752 & 0.179 & 5.366 \\
\hline $\begin{array}{c}\text { Families by age groups } \\
\qquad=29 \\
30-39 \\
40-49 \\
50-59 \\
60-69 \\
>=70 \\
\end{array}$ & $\begin{array}{l}1699409 \\
5654773 \\
6981205 \\
8765030 \\
5013585 \\
2194882 \\
\end{array}$ & $\begin{array}{l}449 \\
640 \\
821 \\
911 \\
699 \\
538\end{array}$ & $\begin{array}{l}0.047 \\
0.159 \\
0.185 \\
0.198 \\
0.207 \\
0.082\end{array}$ & $\begin{array}{r}2.173 \\
3.217 \\
4.157 \\
5.148 \\
8.086 \\
13.263 \\
\end{array}$ \\
\hline $\begin{array}{c}\text { Singles, head of household, by sex } \\
\text { Males } \\
\text { Females }\end{array}$ & $\begin{array}{r}627444 \\
2121575 \\
\end{array}$ & $\begin{array}{l}582 \\
467 \\
\end{array}$ & $\begin{array}{l}0.118 \\
0.032\end{array}$ & $\begin{array}{r}10.187 \\
7.378\end{array}$ \\
\hline $\begin{array}{c}\text { Singles head of household, by sex } \\
\text { and age group }\end{array}$ & & & & \\
\hline $\begin{array}{l}<=29 \\
30-39 \\
40-49 \\
50-59 \\
60-69 \\
>=70\end{array}$ & $\begin{array}{r}23154 \\
78305 \\
52351 \\
89293 \\
100987 \\
283355\end{array}$ & $\begin{array}{l}399 \\
593 \\
823 \\
759 \\
632 \\
476\end{array}$ & $\begin{array}{r}0.160 \\
0.250 \\
0.191 \\
0.218 \\
0.149 \\
-0.020\end{array}$ & $\begin{array}{r}2.071 \\
3.645 \\
5.374 \\
7.428 \\
10.995 \\
15.542 \\
\end{array}$ \\
\hline $\begin{array}{c}<=29 \\
30-39 \\
40-49 \\
50-50 \\
60-69 \\
>=70\end{array}$ & $\begin{array}{r}45226 \\
141980 \\
323973 \\
507369 \\
438807 \\
664220\end{array}$ & $\begin{array}{l}244 \\
351 \\
483 \\
510 \\
522 \\
429\end{array}$ & \begin{tabular}{r|}
-0.140 \\
-0.033 \\
-0.002 \\
-0.018 \\
0.150 \\
0.018
\end{tabular} & $\begin{array}{r}0.891 \\
2.066 \\
3.593 \\
5.042 \\
7.348 \\
12.780\end{array}$ \\
\hline $\begin{array}{l}\text { Singles by sex } \\
\text { Males } \\
\text { Females } \\
\end{array}$ & $\begin{array}{l}5008932 \\
3460596\end{array}$ & $\begin{array}{l}477 \\
229\end{array}$ & $\begin{array}{r}0.237 \\
-0.094 \\
\end{array}$ & $\begin{array}{l}4.061 \\
5.347 \\
\end{array}$ \\
\hline \begin{tabular}{cc}
\multicolumn{3}{c}{ Singles by sex and age groups } \\
& $<=29$ \\
& $30-39$ \\
Males & $40-49$ \\
& $50-59$ \\
& $60-69$ \\
& $>=70$ \\
\end{tabular} & $\begin{array}{r}2290334 \\
1549371 \\
548633 \\
234320 \\
231884 \\
154391 \\
\end{array}$ & $\begin{array}{l}382 \\
563 \\
673 \\
681 \\
346 \\
213\end{array}$ & $\begin{array}{r}0.199 \\
0.308 \\
0.307 \\
0.280 \\
-0.187 \\
-0.550 \\
\end{array}$ & $\begin{array}{r}2.156 \\
3.648 \\
4.972 \\
6.755 \\
14.191 \\
17.793 \\
\end{array}$ \\
\hline $\begin{array}{l}<=29 \\
30-39 \\
40-49 \\
50-59 \\
60-69 \\
>=70\end{array}$ & \begin{tabular}{r|}
1399090 \\
742858 \\
50915 \\
262687 \\
456544 \\
548503 \\
\end{tabular} & \begin{tabular}{l|}
218 \\
262 \\
272 \\
262 \\
233 \\
191
\end{tabular} & $\begin{array}{r}0.018 \\
0.058 \\
-0.015 \\
-0.099 \\
-0.234 \\
-0.570\end{array}$ & $\begin{array}{r}1.577 \\
2.434 \\
4.276 \\
6.698 \\
9.872 \\
16.381\end{array}$ \\
\hline
\end{tabular}


Table 1.C.2

Saving-Income and Net Worth-Income-Ratios for Detailed Demographic Groups

Low Fertility-Normal Participation Rate, Year 2025

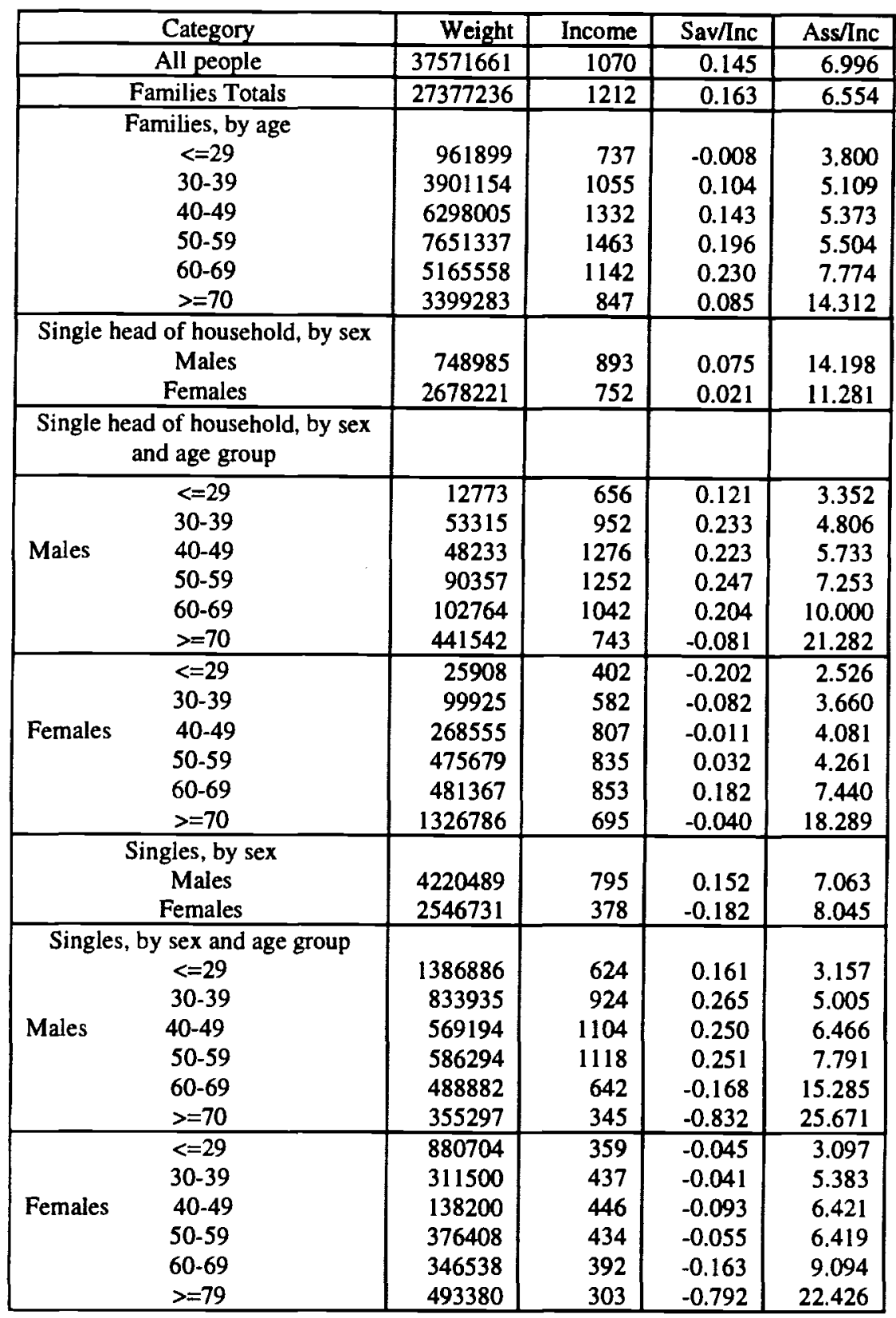


Table 1.C.3

Saving-Income and Net Worth-Income-Ratios for Detailed Demographic Groups

Low Fertility-Normal Participation Rate, Year 2050

\begin{tabular}{|c|c|c|c|c|}
\hline Category & WEIGHT & INCOME & SAV/INC & ASS/INC \\
\hline All people & 28855609 & 1678 & 0.103 & 8.725 \\
\hline Families totals & 20329536 & 1926 & 0.129 & 7.923 \\
\hline $\begin{array}{c}\text { Families by age groups } \\
<=29 \\
30-39 \\
40-49 \\
50-59 \\
60-69 \\
>=70 \\
\end{array}$ & $\begin{array}{r}672217 \\
3042416 \\
4567603 \\
4442428 \\
4305773 \\
3299099 \\
\end{array}$ & $\begin{array}{l}1213 \\
1743 \\
2202 \\
2393 \\
1835 \\
1349\end{array}$ & $\begin{array}{r}-0.047 \\
0.070 \\
0.100 \\
0.149 \\
0.220 \\
0.092 \\
\end{array}$ & $\begin{array}{r}4.785 \\
6.084 \\
6.392 \\
6.835 \\
8.943 \\
14.937 \\
\end{array}$ \\
\hline $\begin{array}{c}\text { Single head of household by sex } \\
\text { Males } \\
\text { Females }\end{array}$ & $\begin{array}{r}763888 \\
2509038 \\
\end{array}$ & $\begin{array}{l}1389 \\
1204 \\
\end{array}$ & $\begin{array}{r}0.028 \\
-0.016 \\
\end{array}$ & $\begin{array}{l}17.828 \\
15.057 \\
\end{array}$ \\
\hline $\begin{array}{l}\text { Single head of household, by } \\
\text { sex and age }\end{array}$ & & & & \\
\hline $\begin{array}{l}<=29 \\
30-39 \\
40-49 \\
50-59 \\
60-69 \\
>=70 \\
\end{array}$ & $\begin{array}{r}9139 \\
41583 \\
35086 \\
53272 \\
95558 \\
529250 \\
\end{array}$ & $\begin{array}{l}1079 \\
1575 \\
2111 \\
2066 \\
1688 \\
1210 \\
\end{array}$ & $\begin{array}{r}0.087 \\
0.203 \\
0.188 \\
0.199 \\
0.201 \\
-0.083 \\
\end{array}$ & $\begin{array}{r}4.212 \\
5.668 \\
6.608 \\
8.592 \\
10.896 \\
23.915 \\
\end{array}$ \\
\hline $\begin{array}{l}<=29 \\
30-39 \\
40-49 \\
50-59 \\
60-69 \\
>=70\end{array}$ & $\begin{array}{r}18010 \\
77797 \\
193200 \\
281099 \\
413414 \\
1525518 \\
\end{array}$ & $\begin{array}{r}665 \\
969 \\
1335 \\
1377 \\
1414 \\
1117 \\
\end{array}$ & $\begin{array}{r}-0.250 \\
-0.129 \\
-0.064 \\
-0.056 \\
0.188 \\
-0.062 \\
\end{array}$ & $\begin{array}{r}3.712 \\
5.112 \\
5.421 \\
6.651 \\
7.778 \\
21.446 \\
\end{array}$ \\
\hline $\begin{array}{c}\text { Singles by sex } \\
\text { Males } \\
\text { Females } \\
\end{array}$ & $\begin{array}{l}3174866 \\
2078282 \\
\end{array}$ & $\begin{array}{r}1232 \\
603 \\
\end{array}$ & $\begin{array}{r}0.079 \\
-0.288 \\
\end{array}$ & $\begin{array}{r}8.736 \\
10.789 \\
\end{array}$ \\
\hline \begin{tabular}{cc}
\multicolumn{3}{c}{ Singles by sex and age group } \\
\\
& $3=29$ \\
Males & $40-39$ \\
& $40-49$ \\
& $50-59$ \\
& $60-69$ \\
& $>=70$ \\
\end{tabular} & $\begin{array}{l}937558 \\
650557 \\
415145 \\
327226 \\
347637 \\
496742 \\
\end{array}$ & $\begin{array}{r}1026 \\
1516 \\
1812 \\
1834 \\
960 \\
562\end{array}$ & $\begin{array}{r}0.135 \\
0.243 \\
0.218 \\
0.205 \\
-0.278 \\
-0.904\end{array}$ & $\begin{array}{r}3.859 \\
5.731 \\
7.329 \\
9.115 \\
17.671 \\
28.443\end{array}$ \\
\hline $\begin{array}{l}<=29 \\
30-39 \\
40-49 \\
50-59 \\
60-69 \\
>=70\end{array}$ & $\begin{array}{l}579857 \\
248842 \\
169829 \\
164351 \\
248177 \\
667225 \\
\end{array}$ & $\begin{array}{l}589 \\
712 \\
731 \\
715 \\
626 \\
506 \\
\end{array}$ & $\begin{array}{l}-0.084 \\
-0.090 \\
-0.170 \\
-0.207 \\
-0.339 \\
-0.645 \\
\end{array}$ & $\begin{array}{r}4.156 \\
6.928 \\
8.486 \\
10.558 \\
13.407 \\
19.242 \\
\end{array}$ \\
\hline
\end{tabular}


Table 1.C.4

\section{Saving-Incomeand Net Worth-Income-Ratios for Detailed Demographic Groups}

Low Fertility-Normal Participation Rate, 2090

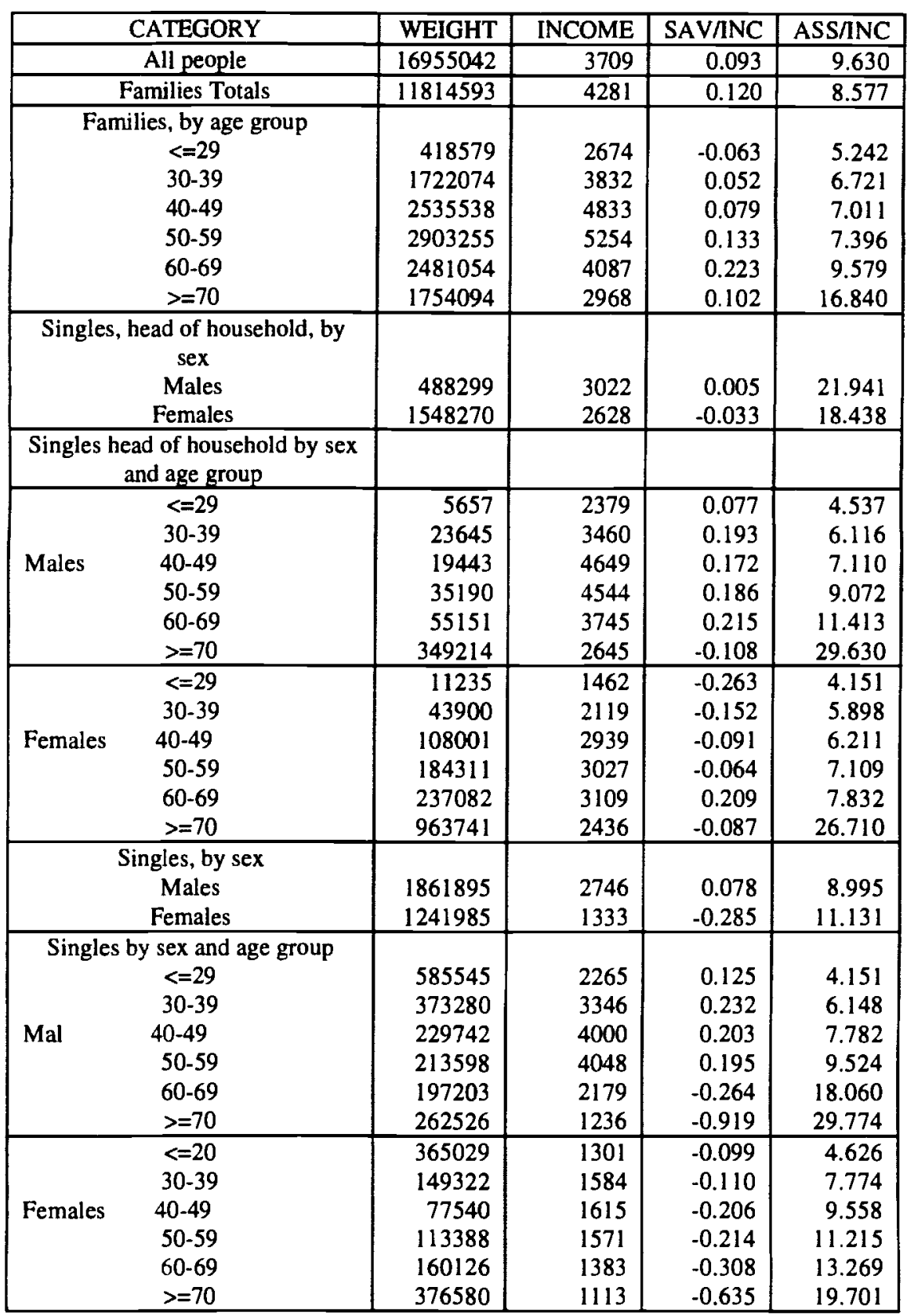


Table 1.D.1

Saving-Income and Net Worth-Income-Ratios for Detailed Demographic Groups

Low Fertility-Reduced Participation Rate, Year 2000

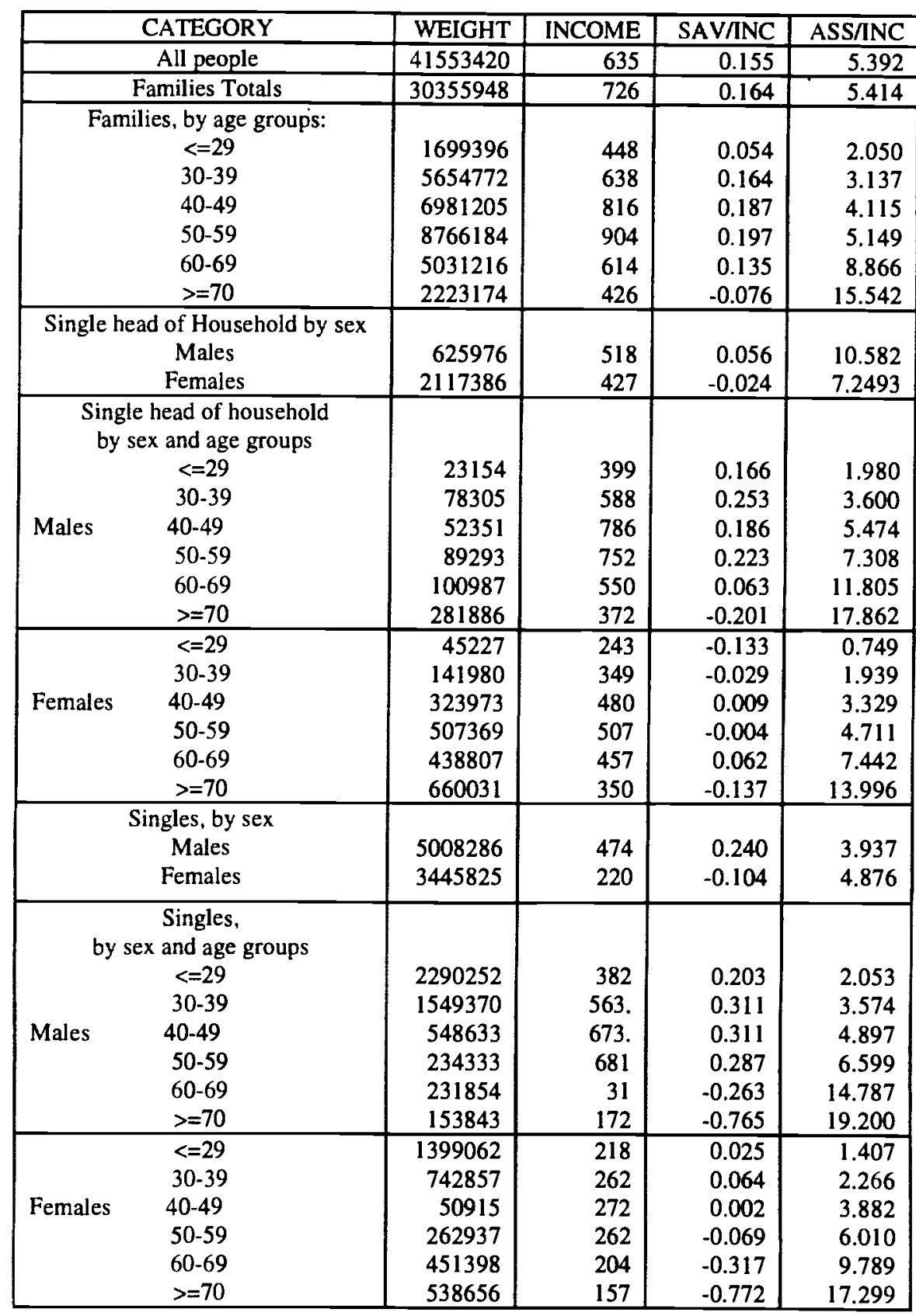


Table 1.D.2

Saving-Income and Net Worth-Income-Ratios for Detailed Demographic Groups

Low Fertility-Reduced Participation Rate, Year 2025

\begin{tabular}{|c|c|c|c|c|}
\hline Category & WEIGHT & INCOME & SAV/NC & ASS/INC \\
\hline All people & 37606669 & 994 & 0.125 & 6.50038 \\
\hline Families Totals & 27455034 & 1129 & 0.143 & 6.23882 \\
\hline $\begin{array}{c}\text { Families by age groups: } \\
\qquad=29 \\
30-39 \\
40-49 \\
50-59 \\
60-69 \\
>=70\end{array}$ & $\begin{array}{r}961904 \\
3901153 \\
6296871 \\
7651323 \\
5175312 \\
3468471 \\
\end{array}$ & $\begin{array}{r}734 \\
1048 \\
1315 \\
1439 \\
942 \\
585 \\
\end{array}$ & $\begin{array}{r}0.024 \\
0.132 \\
0.162 \\
0.202 \\
0.123 \\
-0.146 \\
\end{array}$ & $\begin{array}{r}3.120 \\
4.423 \\
4.967 \\
5.338 \\
8.634 \\
15.310 \\
\end{array}$ \\
\hline $\begin{array}{c}\text { Single head of household by sex } \\
\text { Males } \\
\text { Females }\end{array}$ & $\begin{array}{r}749591 \\
2630548\end{array}$ & $\begin{array}{l}729 \\
628\end{array}$ & $\begin{array}{l}-0.022 \\
-0.082\end{array}$ & $\begin{array}{r}12.697 \\
9.263\end{array}$ \\
\hline $\begin{array}{c}\text { Single Head of Household by sex } \\
\text { and age groups } \\
<=29 \\
30-39 \\
\text { Males } \\
40-49 \\
\\
50-59 \\
60-69 \\
>=70 \\
\end{array}$ & $\begin{array}{r}12773 \\
53315 \\
48225 \\
90358 \\
102764 \\
442157 \\
\end{array}$ & $\begin{array}{r}653 \\
944 \\
1254 \\
1238 \\
857 \\
514 \\
\end{array}$ & $\begin{array}{r}0.145 \\
0.254 \\
0.239 \\
0.255 \\
0.076 \\
-0.334 \\
\end{array}$ & $\begin{array}{r}2.843 \\
4.295 \\
5.393 \\
7.049 \\
11.021 \\
20.296 \\
\end{array}$ \\
\hline $\begin{array}{cc} & <=29 \\
& 30-39 \\
\text { Females } & 40-49 \\
& 50-59 \\
& 60-69 \\
& >=70 \\
\end{array}$ & $\begin{array}{r}25909 \\
99925 \\
268509 \\
475685 \\
481367 \\
1279153 \\
\end{array}$ & $\begin{array}{l}399 \\
573 \\
798 \\
825 \\
697 \\
501 \\
\end{array}$ & $\begin{array}{r}-0.171 \\
-0.051 \\
0.018 \\
0.048 \\
0.036 \\
-0.258 \\
\end{array}$ & $\begin{array}{r}1.833 \\
2.775 \\
3.420 \\
3.868 \\
7.427 \\
16.185 \\
\end{array}$ \\
\hline $\begin{array}{c}\text { Singles by Sex } \\
\text { Males } \\
\text { Females }\end{array}$ & $\begin{array}{l}4230474 \\
2541022\end{array}$ & $\begin{array}{l}777 \\
356\end{array}$ & $\begin{array}{r}0.161 \\
-0.165\end{array}$ & $\begin{array}{l}6.565 \\
6.442\end{array}$ \\
\hline \begin{tabular}{cc}
\multicolumn{2}{c}{ Singles by sex and age groups } \\
& $<=29$ \\
& $30-39$ \\
Males & $40-49$ \\
& $50-59$ \\
& $60-69$ \\
& $>=70$ \\
& \\
& \\
&
\end{tabular} & $\begin{array}{r}1386887 \\
833935 \\
569092 \\
586373 \\
491215 \\
362972 \\
\end{array}$ & $\begin{array}{r}624 \\
924 \\
1104 \\
1118 \\
570 \\
246 \\
\end{array}$ & $\begin{array}{r}0.178 \\
0.286 \\
0.268 \\
0.260 \\
-0.274 \\
-1.225 \\
\end{array}$ & $\begin{array}{r}2.691 \\
4.451 \\
6.075 \\
7.575 \\
16.398 \\
27.628 \\
\end{array}$ \\
\hline $\begin{array}{l}<=29 \\
30-39 \\
40-49 \\
50-59 \\
60-69 \\
>=70\end{array}$ & $\begin{array}{l}880703 \\
311557 \\
138080 \\
376432 \\
346421 \\
487830 \\
\end{array}$ & $\begin{array}{l}359 \\
437 \\
446 \\
434 \\
347 \\
219 \\
\end{array}$ & \begin{tabular}{r|}
-0.015 \\
0.004 \\
-0.046 \\
-0.027 \\
-0.240 \\
-1.019 \\
\end{tabular} & $\begin{array}{r}2.376 \\
4.199 \\
5.353 \\
5.756 \\
9.056 \\
20.114 \\
\end{array}$ \\
\hline
\end{tabular}


Table 1.D.3

\section{Saving-Income and Net Worth-Income-Ratios for Detailed Demographic Groups}

Low Fertility-Reduced Participation Rate, Year 2050

\begin{tabular}{|c|c|c|c|c|}
\hline Category & WEIGHT & INCOME & SAV/INC & ASS/INC \\
\hline All People & 28848450 & 1527 & 0.085 & 7.620 \\
\hline Families Totals & 20429839 & 1762 & 0.112 & 7.217 \\
\hline $\begin{array}{c}\text { Families by age groups } \\
\qquad=29 \\
30-39 \\
40-49 \\
50-59 \\
60-69 \\
>=70 \\
\end{array}$ & $\begin{array}{r}672175 \\
3042007 \\
4567392 \\
4442442 \\
4317314 \\
3388509 \\
\end{array}$ & $\begin{array}{r}1207 \\
1725 \\
2167 \\
2345 \\
1484 \\
950 \\
\end{array}$ & $\begin{array}{r}0.006 \\
0.116 \\
0.140 \\
0.175 \\
0.100 \\
-0.133 \\
\end{array}$ & $\begin{array}{r}3.601 \\
4.927 \\
5.519 \\
6.214 \\
9.761 \\
15.271 \\
\end{array}$ \\
\hline $\begin{array}{c}\text { Single head of household by sex } \\
\text { Males } \\
\text { Females }\end{array}$ & $\begin{array}{r}750257 \\
2400148\end{array}$ & $\begin{array}{r}1088 \\
969\end{array}$ & $\begin{array}{l}-0.083 \\
-0.125\end{array}$ & $\begin{array}{l}14.365 \\
11.039\end{array}$ \\
\hline $\begin{array}{c}\text { Single head of household by sex } \\
\text { and age groups } \\
<=29 \\
30-39 \\
\text { Males } \\
40-49 \\
\\
50-59 \\
60-69 \\
>=70 \\
\end{array}$ & $\begin{array}{r}9139 \\
41578 \\
35085 \\
53273 \\
95544 \\
515640 \\
\end{array}$ & $\begin{array}{r}1075 \\
1556 \\
2064 \\
2040 \\
1360 \\
835 \\
\end{array}$ & $\begin{array}{r}0.130 \\
0.240 \\
0.221 \\
0.227 \\
0.055 \\
-0.308 \\
\end{array}$ & $\begin{array}{r}3.266 \\
4.761 \\
5.881 \\
7.915 \\
11.937 \\
19.846 \\
\end{array}$ \\
\hline $\begin{array}{cc} & <=29 \\
& 30-39 \\
\text { Females } & 40-49 \\
& 50-59 \\
& 60-69 \\
& >=70 \\
\end{array}$ & $\begin{array}{r}18008 \\
77787 \\
193193 \\
281100 \\
413349 \\
1416711 \\
\end{array}$ & $\begin{array}{r}657 \\
947 \\
1315 \\
1358 \\
1142 \\
799 \\
\end{array}$ & $\begin{array}{r}-0.193 \\
-0.073 \\
-0.005 \\
-0.004 \\
0.040 \\
-0.265 \\
\end{array}$ & $\begin{array}{r}2.407 \\
3.558 \\
4.078 \\
5.398 \\
7.435 \\
16.580 \\
\end{array}$ \\
\hline $\begin{array}{l}\text { Singles, by sex } \\
\text { Males } \\
\text { Females }\end{array}$ & $\begin{array}{l}3199544 \\
2068662\end{array}$ & $\begin{array}{r}1186 \\
545\end{array}$ & $\begin{array}{r}0.100 \\
-0.269\end{array}$ & $\begin{array}{l}7.698 \\
8.256\end{array}$ \\
\hline $\begin{array}{c}\text { Singles, by sex and age groups } \\
<=29 \\
\\
\text { Males } \\
30-39 \\
40-49 \\
\\
50-59 \\
60-69 \\
>=70 \\
\end{array}$ & $\begin{array}{l}937511 \\
650475 \\
415124 \\
327289 \\
350024 \\
519120\end{array}$ & $\begin{array}{r}1026 \\
1516 \\
1812 \\
1834 \\
825 \\
398 \\
\end{array}$ & $\begin{array}{r}0.169 \\
0.278 \\
0.254 \\
0.235 \\
-0.414 \\
-1.301\end{array}$ & $\begin{array}{r}3.022 \\
4.813 \\
6.523 \\
8.394 \\
18.817 \\
29.934 \\
\end{array}$ \\
\hline $\begin{array}{c}<=29 \\
30-39 \\
40-49 \\
50-59 \\
60-69 \\
>=70\end{array}$ & $\begin{array}{l}579834 \\
248805 \\
169804 \\
164340 \\
248290 \\
657588 \\
\end{array}$ & $\begin{array}{l}589 \\
712 \\
731 \\
715 \\
503 \\
367 \\
\end{array}$ & $\begin{array}{l}-0.030 \\
-0.016 \\
-0.075 \\
-0.113 \\
-0.491 \\
-0.853 \\
\end{array}$ & $\begin{array}{r}2.853 \\
4.951 \\
6.338 \\
8.325 \\
13.136 \\
16.748 \\
\end{array}$ \\
\hline
\end{tabular}


Table 1.D.4

Saving-Income and Net Worth-Income-Ratios for Detailed Demographic Groups

Low Fertility- Reduced Participation Rate, Year 2090

\begin{tabular}{|c|c|c|c|c|}
\hline CATEGORY & WEIGHT & INCOME & SAV/INC & ASS/INC \\
\hline All people & 16919064 & 3395 & 0.078 & 8.197 \\
\hline Families Totals & 11838597 & 3946 & 0.107 & 7.661 \\
\hline $\begin{array}{c}\text { Families, by age group } \\
\qquad=29 \\
30-39 \\
40-49 \\
50-59 \\
60-69 \\
>=70 \\
\end{array}$ & $\begin{array}{r}418556 \\
1721938 \\
2535257 \\
1903107 \\
2578312 \\
1781425 \\
\end{array}$ & $\begin{array}{l}2663 \\
3799 \\
4767 \\
5162 \\
3338 \\
2085 \\
\end{array}$ & $\begin{array}{r}-0.007 \\
0.103 \\
0.126 \\
0.165 \\
0.104 \\
-0.139 \\
\end{array}$ & $\begin{array}{r}3.981 \\
5.408 \\
5.977 \\
6.617 \\
10.175 \\
16.830 \\
\end{array}$ \\
\hline $\begin{array}{c}\text { Singles head of household, by sex } \\
\text { Males } \\
\text { Females } \\
\end{array}$ & $\begin{array}{r}475851 \\
1479397 \\
\end{array}$ & $\begin{array}{l}2357 \\
2113 \\
\end{array}$ & $\begin{array}{l}-0.113 \\
-0.152 \\
\end{array}$ & $\begin{array}{l}16.685 \\
13.023 \\
\end{array}$ \\
\hline $\begin{array}{l}\text { Singles head of household, by sex } \\
\text { and age group }\end{array}$ & & & & \\
\hline $\begin{array}{l}<=29 \\
30-39 \\
40-49 \\
50-59 \\
60-69 \\
>=70 \\
\end{array}$ & $\begin{array}{r}5656 \\
23643 \\
19441 \\
35189 \\
55148 \\
336773 \\
\end{array}$ & $\begin{array}{l}2371 \\
3425 \\
4560 \\
4495 \\
3043 \\
1819 \\
\end{array}$ & $\begin{array}{r}0.123 \\
0.234 \\
0.211 \\
0.219 \\
0.064 \\
-0.346 \\
\end{array}$ & $\begin{array}{r}3.524 \\
5.081 \\
6.249 \\
8.300 \\
12.425 \\
23.350 \\
\end{array}$ \\
\hline $\begin{array}{l}<=29 \\
30-39 \\
40-49 \\
50-59 \\
60-69 \\
>=70 \\
\end{array}$ & $\begin{array}{r}11234 \\
43896 \\
107989 \\
184303 \\
237071 \\
894904 \\
\end{array}$ & $\begin{array}{l}1448 \\
2079 \\
2901 \\
2990 \\
2527 \\
1737 \\
\end{array}$ & $\begin{array}{r}-0.203 \\
-0.088 \\
-0.026 \\
-0.013 \\
0.044 \\
-0.305 \\
\end{array}$ & \begin{tabular}{r|}
2.761 \\
4.147 \\
4.732 \\
5.911 \\
7.872 \\
19.823 \\
\end{tabular} \\
\hline $\begin{array}{c}\text { Singles, by sex } \\
\text { Males } \\
\text { Females } \\
\end{array}$ & $\begin{array}{l}1878568 \\
1246651 \\
\end{array}$ & $\begin{array}{l}2650 \\
1205 \\
\end{array}$ & $\begin{array}{r}0.097 \\
-0.292 \\
\end{array}$ & $\begin{array}{l}7.987 \\
9.178 \\
\end{array}$ \\
\hline 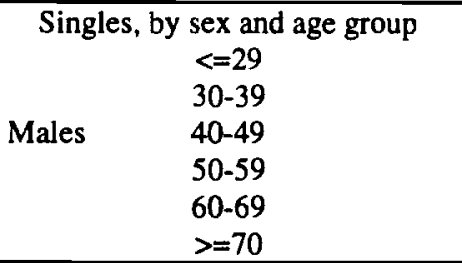 & $\begin{array}{l}585512 \\
373253 \\
229717 \\
213653 \\
199233 \\
277201\end{array}$ & $\begin{array}{r}2265 \\
3346 \\
4000 \\
4048 \\
1889 \\
874\end{array}$ & $\begin{array}{r}0.161 \\
0.269 \\
0.251 \\
0.226 \\
-0.399 \\
-1.373\end{array}$ & $\begin{array}{r}3.285 \\
5.153 \\
6.908 \\
8.788 \\
19.151 \\
32.240\end{array}$ \\
\hline $\begin{array}{l}<=29 \\
30-39 \\
40-49 \\
50-59 \\
60-69 \\
>=70\end{array}$ & $\begin{array}{r}365008 \\
149315 \\
77526 \\
113367 \\
159678 \\
381756\end{array}$ & $\begin{array}{r}1301 \\
1584 \\
1615 \\
1571 \\
1131 \\
805\end{array}$ & $\begin{array}{l}-0.043 \\
-0.031 \\
-0.109 \\
-0.134 \\
-0.488 \\
-0.928\end{array}$ & $\begin{array}{r}3.276 \\
5.675 \\
7.360 \\
9.330 \\
13.868 \\
18.892\end{array}$ \\
\hline
\end{tabular}


Table 2.A

Demographic Structure by Age and Family Type

\section{5: Actual}

MALE

\begin{tabular}{|r|r|r|r|r|r|r|}
\hline Age & \multicolumn{1}{|c|}{$\begin{array}{c}\text { Total } \\
\text { Population }\end{array}$} & $\begin{array}{c}\text { Married } \\
\text { without } \\
\text { Children }\end{array}$ & $\begin{array}{c}\text { Married } \\
\text { with } \\
\text { Children }\end{array}$ & $\begin{array}{c}\text { Single Head } \\
\text { of } \\
\text { Household }\end{array}$ & $\begin{array}{c}\text { Single } \\
\text { Independent }\end{array}$ & Dependent \\
\hline $0 \sim 19$ & 17941 & 0 & 0 & 0 & 370 & 17573 \\
\hline $20 \sim 29$ & 8114 & 605 & 982 & 76 & 3104 & 3349 \\
\hline $30 \sim 39$ & 10108 & 783 & 6864 & 145 & 757 & 1558 \\
\hline $40 \sim 49$ & 8551 & 794 & 7181 & 53 & 230 & 293 \\
\hline $50 \sim 59$ & 6646 & 4063 & 2160 & 64 & 193 & 166 \\
\hline $60 \sim 69$ & 4191 & 2620 & 696 & 54 & 115 & 706 \\
\hline $70 \&$ Over & 2940 & 1000 & 254 & 67 & 130 & 1489 \\
\hline TOTAL & 58491 & 9865 & 18137 & 459 & 4899 & 25135 \\
\hline
\end{tabular}

FEMALE

\begin{tabular}{|r|r|r|r|r|r|r|}
\hline \multicolumn{1}{|c|}{ Age } & \multicolumn{1}{|c|}{$\begin{array}{c}\text { Total } \\
\text { Population }\end{array}$} & $\begin{array}{c}\text { Married } \\
\text { without } \\
\text { Children }\end{array}$ & $\begin{array}{c}\text { Married } \\
\text { with } \\
\text { Children }\end{array}$ & $\begin{array}{c}\text { Single Head } \\
\text { of } \\
\text { Household }\end{array}$ & $\begin{array}{c}\text { Single } \\
\text { Independent }\end{array}$ & Dependent \\
\hline $0 \sim 19$ & 17081 & 10 & 5 & 0 & 255 & 16811 \\
\hline $20 \sim 29$ & 7904 & 812 & 2045 & 35 & 1516 & 3496 \\
\hline $30 \sim 39$ & 10646 & 685 & 8393 & 164 & 209 & 1196 \\
\hline $40 \sim 49$ & 8259 & 1633 & 5819 & 320 & 191 & 296 \\
\hline $50 \sim 59$ & 6889 & 4356 & 1211 & 300 & 439 & 583 \\
\hline $60 \sim 69$ & 5354 & 1993 & 563 & 213 & 742 & 1069 \\
\hline $70 \&$ over & 4320 & 376 & 99 & 77 & 500 & 3268 \\
\hline TOTAL & 60453 & 9865 & 18135 & 1109 & 3852 & 27493 \\
\hline
\end{tabular}


Table 2.B.1

Demographic Structure by Age and Family Type

2000 : Mid Fertility-Normal Participation Rate

MALE

\begin{tabular}{|r|r|r|r|r|r|r|}
\hline Age & \multicolumn{1}{|c|}{$\begin{array}{c}\text { Total } \\
\text { Population }\end{array}$} & $\begin{array}{c}\text { Married } \\
\text { without } \\
\text { Children }\end{array}$ & $\begin{array}{c}\text { Married } \\
\text { with } \\
\text { Children }\end{array}$ & $\begin{array}{c}\text { Single Head } \\
\text { of } \\
\text { Household }\end{array}$ & $\begin{array}{c}\text { Single } \\
\text { Independent }\end{array}$ & Dependent \\
\hline $0 \sim 19$ & 13270 & 0 & 0 & 0 & 38 & 13232 \\
\hline $20 \sim 29$ & 9287 & 814 & 885 & 23 & 2253 & 5313 \\
\hline $30 \sim 39$ & 8701 & 956 & 4699 & 78 & 1549 & 1419 \\
\hline $40 \sim 49$ & 8334 & 1760 & 5221 & 52 & 549 & 752 \\
\hline $50 \sim 59$ & 9662 & 6277 & 2487 & 89 & 234 & 575 \\
\hline $60 \sim 69$ & 6536 & 4827 & 187 & 101 & 232 & 1189 \\
\hline $70 \&$ over & 5445 & 1954 & 241 & 283 & 154 & 2813 \\
\hline TOTAL & 61236 & 16588 & 13720 & 626 & 5009 & 25293 \\
\hline
\end{tabular}

FEMALE

\begin{tabular}{|r|r|r|r|r|r|r|}
\hline \multicolumn{1}{|c|}{ Age } & \multicolumn{1}{|c|}{$\begin{array}{c}\text { Total } \\
\text { Population }\end{array}$} & $\begin{array}{c}\text { Married } \\
\text { without } \\
\text { Children }\end{array}$ & $\begin{array}{c}\text { Married } \\
\text { with } \\
\text { Children }\end{array}$ & $\begin{array}{c}\text { Single Head } \\
\text { of } \\
\text { Household }\end{array}$ & $\begin{array}{c}\text { Single } \\
\text { Independent }\end{array}$ & Dependent \\
\hline $0 \sim 19$ & 12717 & 0 & 0 & 0 & 36 & 12681 \\
\hline $20 \sim 29$ & 8853 & 988 & 1331 & 45 & 1364 & 5125 \\
\hline $30 \sim 39$ & 8429 & 908 & 5137 & 142 & 742 & 1500 \\
\hline $40 \sim 49$ & 9103 & 2654 & 5824 & 324 & 51 & 250 \\
\hline $50 \sim 59$ & 10063 & 7128 & 1104 & 507 & 263 & 1061 \\
\hline $60 \sim 69$ & 6838 & 3745 & 150 & 439 & 457 & 2047 \\
\hline 70 \& Over & 8379 & 1165 & 174 & 664 & 549 & 5827 \\
\hline TOTAL & 64382 & 16588 & 13720 & 2121 & 3462 & 28491 \\
\hline
\end{tabular}


Table 2.B.2

\section{Demographic Structure by Age and Family Type}

\section{5 : Mid Fertility-Normal Participation Rate}

MALE

\begin{tabular}{|r|r|r|r|r|r|r|}
\hline Age & \multicolumn{1}{|c|}{$\begin{array}{c}\text { Total } \\
\text { Population }\end{array}$} & $\begin{array}{c}\text { Married } \\
\text { without } \\
\text { Children }\end{array}$ & $\begin{array}{c}\text { Married } \\
\text { with } \\
\text { Children }\end{array}$ & $\begin{array}{c}\text { Single Head } \\
\text { of } \\
\text { Household }\end{array}$ & $\begin{array}{c}\text { Single } \\
\text { Independent }\end{array}$ & Dependent \\
\hline $0 \sim 19$ & 12196 & 0 & 0 & 0 & 36 & 12160 \\
\hline $20 \sim 29$ & 6750 & 528 & 566 & 14 & 1583 & 4059 \\
\hline $30 \sim 39$ & 6061 & 752 & 3224 & 55 & 860 & 1170 \\
\hline $40 \sim 49$ & 7689 & 1009 & 5287 & 48 & 569 & 776 \\
\hline $50 \sim 59$ & 9084 & 3816 & 3836 & 99 & 583 & 750 \\
\hline $60 \sim 69$ & 6889 & 4693 & 466 & 115 & 486 & 1129 \\
\hline 70 \& over & 10606 & 3276 & 99 & 443 & 356 & 6432 \\
\hline TOTAL & 59275 & 14074 & 13478 & 774 & 4473 & 26476 \\
\hline
\end{tabular}

FEMALE

\begin{tabular}{|r|r|r|r|r|r|r|}
\hline Age & \multicolumn{1}{|c|}{$\begin{array}{c}\text { Total } \\
\text { Population }\end{array}$} & $\begin{array}{c}\text { Married } \\
\text { without } \\
\text { Children }\end{array}$ & $\begin{array}{c}\text { Married } \\
\text { with } \\
\text { Children }\end{array}$ & $\begin{array}{c}\text { Single Head } \\
\text { of } \\
\text { Household }\end{array}$ & $\begin{array}{c}\text { Single } \\
\text { Independent }\end{array}$ & Dependent \\
\hline $0 \sim 19$ & 11717 & 0 & 0 & 0 & 34 & 11683 \\
\hline $20 \sim 29$ & 6493 & 636 & 846 & 30 & 1012 & 3969 \\
\hline $30 \sim 39$ & 5885 & 786 & 3710 & 102 & 331 & 956 \\
\hline $40 \sim 49$ & 7573 & 1185 & 5578 & 269 & 139 & 402 \\
\hline $50 \sim 59$ & 9127 & 4241 & 3033 & 493 & 371 & 989 \\
\hline $60 \sim 69$ & 7760 & 4632 & 237 & 509 & 338 & 2044 \\
\hline 70 \& over & 15812 & 2593 & 73 & 1327 & 494 & 11325 \\
\hline TOTAL & 64367 & 14073 & 13477 & 2730 & 2719 & 31368 \\
\hline
\end{tabular}


Table 2.B.3

\section{Demographic Structure by Age and Family Type}

\section{0 : Mid Fertility-Normal Participation Rate}

MALE

\begin{tabular}{|r|r|r|r|r|r|r|}
\hline Age & \multicolumn{1}{|c|}{$\begin{array}{c}\text { Total } \\
\text { Population }\end{array}$} & $\begin{array}{c}\text { Married } \\
\text { without } \\
\text { Children }\end{array}$ & $\begin{array}{c}\text { Married } \\
\text { with } \\
\text { Children }\end{array}$ & $\begin{array}{l}\text { Single Head } \\
\text { of } \\
\text { Household }\end{array}$ & $\begin{array}{c}\text { Sngle } \\
\text { Independent }\end{array}$ & Dependent \\
\hline $0 \sim 19$ & 10712 & 0 & 0 & 0 & 27 & 10685 \\
\hline $20 \sim 29$ & 5212 & 440 & 441 & 12 & 1229 & 3090 \\
\hline $30 \sim 39$ & 5828 & 729 & 3105 & 52 & 822 & 1120 \\
\hline $40 \sim 49$ & 6839 & 761 & 4832 & 43 & 510 & 693 \\
\hline $50 \sim 59$ & 5777 & 2359 & 2506 & 63 & 357 & 492 \\
\hline $60 \sim 69$ & 5761 & 3915 & 396 & 112 & 344 & 994 \\
\hline 70 \& Over & 10501 & 3215 & 91 & 576 & 491 & 6128 \\
\hline TOTAL & 50630 & 11419 & 11371 & 858 & 3780 & 23202 \\
\hline
\end{tabular}

FEMALE

\begin{tabular}{|r|r|r|r|r|r|r|}
\hline Age & \multicolumn{1}{|c|}{$\begin{array}{c}\text { Total } \\
\text { Population }\end{array}$} & $\begin{array}{c}\text { Married } \\
\text { without } \\
\text { Children }\end{array}$ & $\begin{array}{c}\text { Married } \\
\text { with } \\
\text { Children }\end{array}$ & $\begin{array}{c}\text { Single Head } \\
\text { of } \\
\text { Household }\end{array}$ & $\begin{array}{c}\text { Single } \\
\text { Independent }\end{array}$ & Dependent \\
\hline $0 \sim 19$ & 10292 & 0 & 0 & 0 & 26 & 10266 \\
\hline $20 \sim 29$ & 5013 & 554 & 697 & 24 & 761 & 2977 \\
\hline $30 \sim 39$ & 5657 & 747 & 3572 & 98 & 319 & 921 \\
\hline $40 \sim 49$ & 6728 & 789 & 4817 & 236 & 228 & 658 \\
\hline $50 \sim 59$ & 5861 & 2764 & 1991 & 317 & 201 & 588 \\
\hline $60 \sim 69$ & 6244 & 3881 & 222 & 451 & 239 & 1451 \\
\hline 70 \& over & 15812 & 2683 & 72 & 1594 & 650 & 10813 \\
\hline TOTAL & 55607 & 11418 & 11371 & 2720 & 2424 & 27674 \\
\hline
\end{tabular}


Table 2.C.1

\section{Demographic Structure by Age and Family Type}

\section{0: Low Fertility-Normal Participation Rate}

MALE

\begin{tabular}{|r|r|r|r|r|r|r|}
\hline \multicolumn{1}{|c|}{ Age } & \multicolumn{1}{|c|}{$\begin{array}{c}\text { Total } \\
\text { Population }\end{array}$} & $\begin{array}{c}\text { Married } \\
\text { without } \\
\text { Children }\end{array}$ & $\begin{array}{c}\text { Married } \\
\text { with } \\
\text { Children }\end{array}$ & $\begin{array}{l}\text { Single Head } \\
\text { of } \\
\text { Household }\end{array}$ & $\begin{array}{c}\text { Single } \\
\text { Independent }\end{array}$ & Dependent \\
\hline $0 \sim 19$ & 12729 & 0 & 0 & 0 & 38 & 12691 \\
\hline $20 \sim 29$ & 9288 & 878 & 822 & 23 & 2253 & 5312 \\
\hline $30 \sim 39$ & 8701 & 1164 & 4490 & 78 & 1549 & 1420 \\
\hline $40 \sim 49$ & 8334 & 1803 & 5178 & 52 & 549 & 752 \\
\hline $50 \sim 59$ & 9662 & 6274 & 2492 & 89 & 234 & 573 \\
\hline $60 \sim 69$ & 6536 & 4827 & 187 & 101 & 232 & 1189 \\
\hline $70 \&$ Over & 5445 & 1954 & 241 & 283 & 154 & 2813 \\
\hline TOTAL & 60694 & 16900 & 13410 & 626 & 5009 & 24750 \\
\hline
\end{tabular}

FEMALE

\begin{tabular}{|r|r|r|r|r|r|r|}
\hline Age & \multicolumn{1}{|c|}{$\begin{array}{c}\text { Total } \\
\text { Population }\end{array}$} & $\begin{array}{c}\text { Married } \\
\text { without } \\
\text { Children }\end{array}$ & $\begin{array}{c}\text { Married } \\
\text { with } \\
\text { Children }\end{array}$ & $\begin{array}{l}\text { Single Head } \\
\text { of } \\
\text { Household }\end{array}$ & $\begin{array}{c}\text { Single } \\
\text { Independent }\end{array}$ & Dependent \\
\hline $0 \sim 19$ & 12197 & 0 & 0 & 0 & 36 & 12161 \\
\hline $20 \sim 29$ & 8853 & 1067 & 1253 & 450 & 1364 & 4719 \\
\hline $30 \sim 39$ & 8429 & 1137 & 4907 & 142 & 743 & 1500 \\
\hline $40 \sim 49$ & 9104 & 2659 & 5819 & 324 & 51 & 251 \\
\hline $50-59$ & 10063 & 7127 & 1105 & 507 & 263 & 1061 \\
\hline $60 \sim 69$ & 6838 & 3745 & 150 & 439 & 457 & 2047 \\
\hline $70 \&$ Over & 8379 & 1165 & 174 & 664 & 549 & 5827 \\
\hline TOTAL & 63862 & 16900 & 13408 & 2526 & 3463 & 27566 \\
\hline
\end{tabular}


Table 2.C.2

Demographic Structure by Age and Family Type

2025 : Low Fertility-Normal Participation Rate

MALE

\begin{tabular}{|r|r|r|r|r|r|r|}
\hline Age & \multicolumn{1}{|c|}{$\begin{array}{c}\text { Total } \\
\text { Population }\end{array}$} & $\begin{array}{c}\text { Married } \\
\text { without } \\
\text { Children }\end{array}$ & $\begin{array}{c}\text { Married } \\
\text { with } \\
\text { Children }\end{array}$ & $\begin{array}{c}\text { Single Head } \\
\text { of } \\
\text { Household }\end{array}$ & $\begin{array}{c}\text { Single } \\
\text { Independent }\end{array}$ & Dependent \\
\hline $0 \sim 19$ & 9636 & 0 & 0 & 0 & 29 & 9607 \\
\hline $20 \sim 29$ & 5756 & 541 & 421 & 13 & 1358 & 3423 \\
\hline $30 \sim 39$ & 5924 & 1050 & 2852 & 53 & 834 & 1135 \\
\hline $40 \sim 49$ & 7690 & 1557 & 4741 & 48 & 569 & 775 \\
\hline $50 \sim 59$ & 9084 & 4603 & 3048 & 90 & 586 & 757 \\
\hline $60 \sim 69$ & 6888 & 4832 & 324 & 103 & 489 & 1140 \\
\hline $70 \&$ Over & 10606 & 3276 & 97 & 442 & 356 & 6435 \\
\hline TOTAL & 55583 & 15859 & 11483 & 749 & 4221 & 23272 \\
\hline
\end{tabular}

FEMALE

\begin{tabular}{|r|r|r|r|r|r|r|}
\hline \multicolumn{1}{|c|}{ Age } & \multicolumn{1}{|c|}{$\begin{array}{c}\text { Total } \\
\text { Population }\end{array}$} & $\begin{array}{c}\text { Married } \\
\text { without } \\
\text { Children }\end{array}$ & $\begin{array}{c}\text { Married } \\
\text { with } \\
\text { Children }\end{array}$ & $\begin{array}{c}\text { Single Head } \\
\text { of } \\
\text { Household }\end{array}$ & $\begin{array}{c}\text { Single } \\
\text { Independent }\end{array}$ & Dependent \\
\hline $0 \sim 19$ & 9258 & 0 & 0 & 0 & 28 & 9230 \\
\hline $20 \sim 29$ & 5536 & 674 & 659 & 26 & 853 & 3324 \\
\hline $30 \sim 39$ & 5751 & 117 & 3323 & 100 & 312 & 899 \\
\hline $40 \sim 49$ & 7574 & 1817 & 4951 & 269 & 138 & 399 \\
\hline $50 \sim 59$ & 9127 & 4971 & 2300 & 476 & 376 & 1004 \\
\hline $60 \sim 69$ & 7760 & 4690 & 176 & 481 & 347 & 2066 \\
\hline 70 Over & 15812 & 2591 & 73 & 1328 & 494 & 11326 \\
\hline TOTAL & 60817 & 15860 & 11482 & 2680 & 2548 & 28248 \\
\hline
\end{tabular}


Table 2.C.3

Demographic Structure by Age and Family Type

2050 : Low Fertility-Normal Participation Rate

MALE

\begin{tabular}{|r|r|r|r|r|r|r|}
\hline \multicolumn{1}{|c|}{ Age } & \multicolumn{1}{|c|}{$\begin{array}{c}\text { Total } \\
\text { Population }\end{array}$} & $\begin{array}{c}\text { Married } \\
\text { without } \\
\text { Children }\end{array}$ & $\begin{array}{c}\text { Married } \\
\text { with } \\
\text { Children }\end{array}$ & $\begin{array}{c}\text { Single Head } \\
\text { of } \\
\text { Household }\end{array}$ & $\begin{array}{c}\text { Single } \\
\text { Independent }\end{array}$ & Dependent \\
\hline $0 \sim 19$ & 7014 & 0 & 0 & 0 & 19 & 6995 \\
\hline $20 \sim 29$ & 3871 & 387 & 285 & 9 & 919 & 2271 \\
\hline $30 \sim 39$ & 4620 & 820 & 2223 & 42 & 651 & 884 \\
\hline $40 \sim 49$ & 5583 & 1037 & 3531 & 35 & 415 & 565 \\
\hline $50 \sim 59$ & 5275 & 2660 & 1782 & 53 & 327 & 453 \\
\hline $60 \sim 69$ & 5762 & 4035 & 270 & 96 & 348 & 1013 \\
\hline $70 \&$ over & 10500 & 3253 & 46 & 529 & 497 & 6175 \\
\hline TOTAL & 42625 & 12192 & 8137 & 764 & 3176 & 18356 \\
\hline
\end{tabular}

FEMALE

\begin{tabular}{|r|r|r|r|r|r|r|}
\hline Age & \multicolumn{1}{|c|}{$\begin{array}{c}\text { Total } \\
\text { Population }\end{array}$} & $\begin{array}{c}\text { Married } \\
\text { without } \\
\text { Children }\end{array}$ & $\begin{array}{c}\text { Married } \\
\text { with } \\
\text { Children }\end{array}$ & $\begin{array}{c}\text { Single Head } \\
\text { of } \\
\text { Household }\end{array}$ & $\begin{array}{c}\text { Single } \\
\text { Independent }\end{array}$ & Dependent \\
\hline $0 \sim 19$ & 6739 & 0 & 0 & 0 & 18 & 6721 \\
\hline $20 \sim 29$ & 3722 & 499 & 466 & 18 & 562 & 2177 \\
\hline $30 \sim 39$ & 4484 & 860 & 2579 & 78 & 249 & 718 \\
\hline $40 \sim 49$ & 5498 & 1111 & 3534 & 193 & 170 & 490 \\
\hline $50 \sim 59$ & 5367 & 3062 & 1377 & 281 & 164 & 483 \\
\hline $60 \sim 69$ & 6243 & 3943 & 147 & 413 & 248 & 1504 \\
\hline 70 \& over & 15813 & 2719 & 35 & 1526 & 667 & 10866 \\
\hline TOTAL & 47866 & 12183 & 8137 & 2509 & 2078 & 22959 \\
\hline
\end{tabular}


Table 2.C.4

Demographic Structure by Age and Family Type

2090 : Low Fertility-Normal Participation Rate

MALE

\begin{tabular}{|r|r|r|r|r|r|r|}
\hline \multicolumn{1}{|c|}{ Age } & \multicolumn{1}{|c|}{$\begin{array}{c}\text { Total } \\
\text { Population }\end{array}$} & $\begin{array}{c}\text { Married } \\
\text { without } \\
\text { Children }\end{array}$ & $\begin{array}{c}\text { Married } \\
\text { with } \\
\text { Children }\end{array}$ & $\begin{array}{c}\text { Single Head } \\
\text { of } \\
\text { Household }\end{array}$ & $\begin{array}{c}\text { Single } \\
\text { Independent }\end{array}$ & Dependent \\
\hline $0 \sim 19$ & 4022 & 0 & 0 & 0 & 11 & 4010 \\
\hline $20 \sim 29$ & 2414 & 238 & 180 & 6 & 574 & 1416 \\
\hline $30 \sim 39$ & 2627 & 456 & 1266 & 24 & 373 & 508 \\
\hline $40 \sim 49$ & 3098 & 601 & 1934 & 19 & 230 & 313 \\
\hline $50 \sim 59$ & 3448 & 1766 & 1138 & 35 & 214 & 295 \\
\hline $60 \sim 69$ & 3289 & 2314 & 167 & 55 & 197 & 555 \\
\hline 70 \& Over & 5915 & 1736 & 18 & 349 & 263 & 3550 \\
\hline TOTAL & 24812 & 7111 & 4703 & 488 & 1862 & 10647 \\
\hline
\end{tabular}

FEMALE

\begin{tabular}{|r|r|r|r|r|r|r|}
\hline Age & \multicolumn{1}{|c|}{$\begin{array}{c}\text { Total } \\
\text { Population }\end{array}$} & $\begin{array}{c}\text { Married } \\
\text { without } \\
\text { Children }\end{array}$ & $\begin{array}{c}\text { Married } \\
\text { with } \\
\text { Children }\end{array}$ & $\begin{array}{c}\text { Single Head } \\
\text { of } \\
\text { Household }\end{array}$ & $\begin{array}{c}\text { Single } \\
\text { Independent }\end{array}$ & Dependent \\
\hline $0 \sim 19$ & 3864 & 0 & 0 & 0 & 110 & 3853 \\
\hline $20 \sim 29$ & 2322 & 301 & 288 & 11 & 354 & 1367 \\
\hline $30 \sim 39$ & 2549 & 474 & 1450 & 44 & 149 & 431 \\
\hline $40 \sim 49$ & 3059 & 672 & 1978 & 108 & 78 & 224 \\
\hline $50 \sim 59$ & 3503 & 1987 & 887 & 184 & 113 & 332 \\
\hline $60 \sim 69$ & 3559 & 2222 & 88 & 237 & 160 & 851 \\
\hline 70 \& over & 9372 & 1455 & 12 & 964 & 377 & 6565 \\
\hline TOTAL & 28228 & 7111 & 4703 & 1548 & 1242 & 13623 \\
\hline
\end{tabular}


Table 2.D.1

Demographic Structure by Age and Family Type

2000 : Low Fertility-Reduced Participation Rate

MALE

\begin{tabular}{|r|r|r|r|r|r|r|}
\hline \multicolumn{1}{|c|}{ Age } & \multicolumn{1}{|c|}{$\begin{array}{c}\text { Total } \\
\text { Population }\end{array}$} & $\begin{array}{c}\text { Married } \\
\text { without } \\
\text { Children }\end{array}$ & $\begin{array}{c}\text { Married } \\
\text { with } \\
\text { Children }\end{array}$ & $\begin{array}{c}\text { Single Head } \\
\text { of } \\
\text { Household }\end{array}$ & $\begin{array}{c}\text { Single } \\
\text { Independent }\end{array}$ & Dependent \\
\hline $0 \sim 19$ & 12728 & 0 & 0 & 0 & 37 & 12690 \\
\hline $20 \sim 29$ & 9287 & 878 & 822 & 23 & 2253 & 5311 \\
\hline $30 \sim 39$ & 8701 & 1164 & 4490 & 78 & 1549 & 1420 \\
\hline $40 \sim 49$ & 8334 & 1803 & 5178 & 52 & 549 & 752 \\
\hline $50 \sim 59$ & 9662 & 6275 & 2492 & 89 & 234 & 572 \\
\hline $60 \sim 69$ & 6536 & 4845 & 187 & 101 & 232 & 1171 \\
\hline $70 \&$ over & 5445 & 1983 & 241 & 282 & 154 & 2785 \\
\hline TOTAL & 60693 & 16948 & 13410 & 625 & 5009 & 24701 \\
\hline
\end{tabular}

FEMALE

\begin{tabular}{|r|r|r|r|r|r|r|}
\hline \multicolumn{1}{|c|}{ Age } & \multicolumn{1}{|c|}{$\begin{array}{c}\text { Total } \\
\text { Population }\end{array}$} & $\begin{array}{c}\text { Married } \\
\text { without } \\
\text { Children }\end{array}$ & $\begin{array}{c}\text { Married } \\
\text { with } \\
\text { Children }\end{array}$ & $\begin{array}{c}\text { Single Head } \\
\text { of } \\
\text { Household }\end{array}$ & $\begin{array}{c}\text { Single } \\
\text { Independent }\end{array}$ & Dependent \\
\hline $0 \sim 19$ & 12196 & 0 & 0 & 0 & 36 & 12160 \\
\hline $20 \sim 29$ & 8853 & 1067 & 1253 & 45 & 1364 & 5124 \\
\hline $30 \sim 39$ & 8429 & 1137 & 4907 & 142 & 743 & 1500 \\
\hline $40 \sim 49$ & 9104 & 2659 & 5819 & 324 & 51 & 251 \\
\hline $50 \sim 59$ & 10063 & 7132 & 1105 & 507 & 263 & 1056 \\
\hline $60 \sim 69$ & 6838 & 3768 & 150 & 439 & 451 & 2030 \\
\hline $70 \&$ over & 8379 & 1184 & 174 & 660 & 539 & 5822 \\
\hline TOTAL & 63861 & 16947 & 13408 & 2117 & 3447 & 27943 \\
\hline
\end{tabular}


Table 2.D.2

Demographic Structure by Age and Family Type

2025 : Low Fertility-Reduced Participation Rate

MALE

\begin{tabular}{|r|r|r|r|r|r|r|}
\hline Age & \multicolumn{1}{|c|}{$\begin{array}{c}\text { Total } \\
\text { Population }\end{array}$} & $\begin{array}{c}\text { Married } \\
\text { without } \\
\text { Children }\end{array}$ & $\begin{array}{c}\text { Married } \\
\text { with } \\
\text { Children }\end{array}$ & $\begin{array}{c}\text { Single Head } \\
\text { of } \\
\text { Household }\end{array}$ & $\begin{array}{c}\text { Single } \\
\text { Independent }\end{array}$ & Dependent \\
\hline $0 \sim 19$ & 9635 & 0 & 0 & 0 & 29 & 9606 \\
\hline $20 \sim 29$ & 5756 & 541 & 421 & 13 & 1358 & 3423 \\
\hline $30 \sim 39$ & 5924 & 1050 & 2852 & 53 & 834 & 1135 \\
\hline $40 \sim 49$ & 7689 & 1557 & 4740 & 48 & 569 & 775 \\
\hline $50 \sim 59$ & 9083 & 4603 & 3048 & 90 & 586 & 756 \\
\hline $60 \sim 69$ & 6888 & 4851 & 324 & 103 & 491 & 1119 \\
\hline $70 \&$ over & 10606 & 3372 & 97 & 442 & 363 & 6332 \\
\hline TOTAL & 55581 & 15974 & 11483 & 749 & 4320 & 23147 \\
\hline
\end{tabular}

FEMALE

\begin{tabular}{|r|r|r|r|r|r|r|}
\hline \multicolumn{1}{|c|}{ Age } & \multicolumn{1}{|c|}{$\begin{array}{c}\text { Total } \\
\text { Population }\end{array}$} & $\begin{array}{c}\text { Married } \\
\text { without } \\
\text { Children }\end{array}$ & $\begin{array}{c}\text { Married } \\
\text { with } \\
\text { Children }\end{array}$ & $\begin{array}{c}\text { Single Head } \\
\text { of } \\
\text { Household }\end{array}$ & $\begin{array}{c}\text { Single } \\
\text { Independent }\end{array}$ & Dependent \\
\hline $0 \sim 19$ & 9257 & 0 & 0 & 0 & 28 & 9230 \\
\hline $20 \sim 29$ & 5536 & 674 & 659 & 26 & 853 & 3324 \\
\hline $30 \sim 39$ & 5751 & 1117 & 3323 & 100 & 312 & 899 \\
\hline $40 \sim 49$ & 7572 & 1817 & 4950 & 269 & 138 & 398 \\
\hline $50 \sim 59$ & 9127 & 4971 & 2300 & 476 & 376 & 1004 \\
\hline $60 \sim 69$ & 7760 & 4715 & 176 & 481 & 346 & 2042 \\
\hline 70 \& over & 15812 & 2681 & 73 & 1279 & 488 & 11291 \\
\hline TOTAL & 60815 & 15975 & 11481 & 2631 & 2541 & 28188 \\
\hline
\end{tabular}


Table 2.D.3

Demographic Structure by Age and Family Type

2050 : Low Fertility-Reduced Participation Rate

MALE

\begin{tabular}{|r|r|r|r|r|r|r|}
\hline Age & \multicolumn{1}{|c|}{$\begin{array}{c}\text { Total } \\
\text { Population }\end{array}$} & $\begin{array}{c}\text { Married } \\
\text { without } \\
\text { Children }\end{array}$ & $\begin{array}{c}\text { Married } \\
\text { with } \\
\text { Children }\end{array}$ & $\begin{array}{c}\text { Single Head } \\
\text { of } \\
\text { Household }\end{array}$ & $\begin{array}{c}\text { Single } \\
\text { Independent }\end{array}$ & Dependent \\
\hline $0 \sim 19$ & 7013 & 0 & 0 & 0 & 19 & 6994 \\
\hline $20 \sim 29$ & 3871 & 387 & 285 & 9 & 919 & 2271 \\
\hline $30 \sim 39$ & 4620 & 820 & 2222 & 42 & 651 & 883 \\
\hline $40 \sim 49$ & 5583 & 1037 & 3531 & 35 & 415 & 565 \\
\hline $50 \sim 59$ & 5275 & 2660 & 1782 & 53 & 327 & 453 \\
\hline $60 \sim 69$ & 5761 & 4047 & 270 & 96 & 350 & 998 \\
\hline $70 \&$ over & 10500 & 3342 & 46 & 516 & 519 & 6077 \\
\hline TOTAL & 42623 & 12293 & 8136 & 751 & 3200 & 18241 \\
\hline
\end{tabular}

FEMALE

\begin{tabular}{|c|c|c|c|c|c|c|}
\hline Age & $\begin{array}{c}\text { Total } \\
\text { Population }\end{array}$ & $\begin{array}{l}\text { Married } \\
\text { without } \\
\text { Children }\end{array}$ & $\begin{array}{c}\text { Married } \\
\text { with } \\
\text { Children }\end{array}$ & $\begin{array}{c}\text { Single Head } \\
\text { of } \\
\text { Household }\end{array}$ & $\begin{array}{c}\text { Single } \\
\text { Independent }\end{array}$ & Dependent \\
\hline $0 \sim 19$ & 6738 & 0 & 0 & 0 & 18 & 6721 \\
\hline $20 \sim 29$ & 3722 & 499 & 466 & 18 & 562 & 2177 \\
\hline $30-39$ & 4483 & 860 & 2579 & 78 & 249 & 718 \\
\hline $40-49$ & 5498 & 1111 & 3534 & 193 & 170 & 490 \\
\hline $50-59$ & 5368 & 3061 & 1377 & 281 & 164 & 483 \\
\hline $60 \sim 69$ & 6242 & 3955 & 147 & 413 & 248 & 1479 \\
\hline $70 \&$ over & 15812 & 2808 & 35 & 1417 & 658 & 10894 \\
\hline TOTAL & 47863 & 12294 & 8138 & 2400 & 2069 & 22962 \\
\hline
\end{tabular}


Table 2.D.4

\section{Demographic Structure by Age and Family Type}

\section{0 : Low Fertility-Reduced Participation Rate}

MALE

\begin{tabular}{|r|r|r|r|r|r|r|}
\hline \multicolumn{1}{|c|}{ Age } & \multicolumn{1}{c|}{$\begin{array}{c}\text { Total } \\
\text { Population }\end{array}$} & $\begin{array}{c}\text { Married } \\
\text { without } \\
\text { Children }\end{array}$ & $\begin{array}{c}\text { Married } \\
\text { with } \\
\text { Children }\end{array}$ & $\begin{array}{c}\text { Single Head } \\
\text { of } \\
\text { Household }\end{array}$ & $\begin{array}{c}\text { Single } \\
\text { Independent }\end{array}$ & Dependent \\
\hline $0 \sim 19$ & 4022 & 0 & 0 & 0 & 11 & 4010 \\
\hline $20 \sim 29$ & 2414 & 238 & 180 & 6 & 574 & 1416 \\
\hline $30 \sim 39$ & 2627 & 456 & 1266 & 24 & 373 & 508 \\
\hline $40 \sim 49$ & 3098 & 601 & 1934 & 19 & 230 & 313 \\
\hline $50 \sim 59$ & 3448 & 1766 & 1138 & 35 & 214 & 295 \\
\hline $60 \sim 69$ & 3289 & 2314 & 167 & 55 & 199 & 553 \\
\hline 70 \& over & 5915 & 1736 & 18 & 336 & 277 & 3548 \\
\hline TOTAL & 24812 & 7111 & 4703 & 476 & 1878 & 10643 \\
\hline
\end{tabular}

FEMALE

\begin{tabular}{|r|r|r|r|r|r|r|}
\hline Age & \multicolumn{1}{|c|}{$\begin{array}{c}\text { Total } \\
\text { Population }\end{array}$} & $\begin{array}{c}\text { Married } \\
\text { without } \\
\text { Children }\end{array}$ & $\begin{array}{c}\text { Married } \\
\text { with } \\
\text { Children }\end{array}$ & $\begin{array}{c}\text { Single Head } \\
\text { of } \\
\text { Household }\end{array}$ & $\begin{array}{c}\text { Single } \\
\text { Independent }\end{array}$ & Dependent \\
\hline $0 \sim 19$ & 3864 & 0 & 0 & 0 & 110 & 3853 \\
\hline $20 \sim 29$ & 2322 & 301 & 288 & 11 & 354 & 1367 \\
\hline $30 \sim 39$ & 2549 & 474 & 1450 & 44 & 149 & 431 \\
\hline $40 \sim 49$ & 3059 & 672 & 1978 & 108 & 78 & 224 \\
\hline $50 \sim 59$ & 3503 & 1987 & 887 & 184 & 113 & 332 \\
\hline $60 \sim 69$ & 3559 & 2222 & 88 & 237 & 160 & 851 \\
\hline 70 \& over & 9372 & 1455 & 12 & 895 & 382 & 6628 \\
\hline TOTAL & 28228 & 7111 & 4703 & 1479 & 1247 & 13688 \\
\hline
\end{tabular}


Table 3

Number of persons living in younger households as a percent of total number of persons, (\%) by age.

1979

\begin{tabular}{|c|c|c|c|c|c|c|c|c|c|c|c|c|c|c|c|c|c|c|}
\hline Age & 63 & 64 & 65 & 66 & 67 & 68 & 69 & 70 & 71 & 72 & 73 & 74 & 75 & 76 & 77 & 78 & 79 & 80 \\
\hline$\%$ & 39 & 45 & 47 & 46 & 46 & 51 & 57 & 63 & 57 & 66 & 68 & 71 & 71 & 79 & 72 & 78 & 80 & 77 \\
\hline
\end{tabular}

Table 4

Labor Force Participation Rate by Age and Sex for Japan and the U. S., 1985

\begin{tabular}{|c|r|r|r|r|}
\hline & \multicolumn{3}{|c|}{ United States } & \multicolumn{2}{c|}{ Japan } \\
\hline Age Class & Male & Female & Male & Female \\
\hline $15-19$ & - & - & .173 & .163 \\
\hline $20-24$ & .753 & .641 & .708 & .693 \\
\hline $25-29$ & .871 & .657 & .938 & .509 \\
\hline $30-34$ & .898 & .654 & .953 & .478 \\
\hline $35-39$ & .905 & .676 & .960 & .564 \\
\hline $40-44$ & .902 & .682 & .962 & .644 \\
\hline $45-49$ & .888 & .644 & .957 & .648 \\
\hline $50-54$ & .846 & .581 & .944 & .585 \\
\hline $55-59$ & .761 & .479 & .880 & .490 \\
\hline $60-64$ & .532 & .322 & .699 & .366 \\
\hline $65-69$ & .236 & .130 & .567 & .260 \\
\hline $70-74$ & .144 & .074 & .403 & .151 \\
\hline 75 and over & .068 & .021 & .213 & .055 \\
\hline
\end{tabular}


Table 5.A

\section{Characterization of Disposable Family Income}

\section{Families whose Head is 63 years old or less.}

Dependent Variable: Logarithm of Disposable Income for family including inputed net rent on owner occupied houses and stock of consumer durables.

Parameter Estimates:

\begin{tabular}{|r|r|r|r|r|}
\hline Variable & $\begin{array}{c}\text { Parameter } \\
\text { Estimate }\end{array}$ & Standard Error & $\begin{array}{c}\text { T for HO: } \\
\text { Parameter }=0\end{array}$ & Prob > I I \\
\hline INTERCEP & 5.815795 & 0.06711011 & & \\
A1 & -0.585868 & 0.08071228 & -7.660 & 0.0001 \\
A2 & -0.544488 & 0.04430654 & -12.289 & 0.0001 \\
A3 & -0.414044 & 0.04324100 & -9.575 & 0.0001 \\
A4 & -0.136242 & 0.02624998 & -5.190 & 0.0001 \\
W1 & 0.140866 & 0.00610677 & 23.067 & 0.0001 \\
W2 & -0.128297 & 0.00654585 & -19.600 & 0.0001 \\
W3 & 0.137471 & 0.01696098 & 8.105 & 0.0001 \\
J1 & -0.444220 & 0.06924849 & -6.415 & 0.0001 \\
J2 & -0.605013 & 0.09692799 & -6.242 & 0.0001 \\
J3 & -0.091631 & 0.06907094 & -1.327 & 0.0001 \\
J4 & -0.035346 & 0.07329820 & -0.482 & 0.1846 \\
J5 & -0.399616 & 0.06914294 & -5.780 & 0.6297 \\
J6 & -0.204286 & 0.08324642 & -2.454 & 0.0001 \\
J7 & 0.312768 & 0.07236667 & 4.322 & 0.0141 \\
J8 & -0.127704 & 0.07576449 & -1.686 & 0.0001 \\
J9 & -0.389202 & 0.09183319 & -4.238 & 0.0919 \\
J10 & -0.456900 & 0.07205646 & -6.341 & 0.0001 \\
K1 & 0.005621 & 0.03430894 & 0.164 & 0.0001 \\
K2 & -0.021082 & 0.01225694 & -1.720 & 0.8699 \\
K3 & 0.040992 & 0.01144421 & 3.582 & 0.0854 \\
K4 & 0.010954 & 0.01182141 & 0.927 & 0.0003 \\
K5 & 0.199214 & 0.01501761 & 13.265 & 0.3541 \\
K6 & 0.183693 & 0.02351374 & 7.812 & 0.0001 \\
K7 & -0.009793 & 0.01204089 & -0.813 & 0.0001 \\
K8 & 0.061212 & 0.01973699 & 3.101 & 0.4161 \\
K9 & 0.056987 & 0.00995952 & 5.722 & 0.0001 \\
K10 & -0.259314 & 0.06389020 & -4.059 & 0.0001 \\
K11 & -0.118421 & 0.02412765 & -4.908 & 0.0001 \\
N1 & 0.458667 & 0.02430562 & 18.871 & 0.0001 \\
N2 & 0.649092 & 0.02457094 & 26.417 & 0.0001 \\
N3 & 0.866283 & 0.02522595 & 34.341 & 0.0001 \\
N4 & 1.029918 & 0.02630829 & 39.148 & 0.0001 \\
SEX1 & -0.342904 & 0.00995662 & -34.440 & 0.0001 \\
SEX2 & -0.453395 & 0.01681372 & -26.966 & 0.0001 \\
SEX3 & -0.779584 & 0.01671322 & -46.645 & 0.0001 \\
SS1 & 0.265449 & 0.04141354 & 6.410 & 0.0001
\end{tabular}




\begin{tabular}{|r|r|r|r|r|} 
SS2 & -0.131590 & 0.03775077 & -3.486 & 0.0005 \\
SS3 & 0.010726 & 0.01776967 & 0.604 & 0.5461 \\
SS4 & 0.002057 & 0.03973580 & 0.052 & 0.9587 \\
JX1 & 0.187746 & 0.08281088 & 2.267 & 0.0234 \\
JX2 & 0.048811 & 0.16909915 & 0.289 & 0.7728 \\
JX3 & -0.095624 & 0.08279781 & -1.155 & 0.2481 \\
JX4 & -0.197369 & 0.08566071 & -2.304 & 0.0212 \\
JX5 & 0.236547 & 0.09001907 & 2.628 & 0.0086 \\
JX6 & 0.010496 & 0.13873887 & 0.076 & 0.9397 \\
JX7 & 0.110203 & 0.15637124 & 0.705 & 0.4809 \\
JX8 & 0.108654 & 0.12327221 & 0.881 & 0.3781 \\
JX9 & 0.445982 & 0.18173968 & 2.454 & 0.0141 \\
JX10 & 0.397702 & 0.12196365 & 3.261 & 0.0011 \\
JY1 & 0.474722 & 0.04759274 & 9.975 & 0.0001 \\
JY2 & 0.259136 & 0.11414089 & 2.270 & 0.0232 \\
JY3 & 0.278087 & 0.04755731 & 5.847 & 0.0001 \\
JY4 & 0.142845 & 0.05149936 & 2.774 & 0.0055 \\
JY5 & 0.361656 & 0.04827098 & 7.492 & 0.0001 \\
JY6 & 0.461024 & 0.07232618 & 6.374 & 0.0001 \\
JY7 & 0.190551 & 0.05753860 & 3.312 & 0.0009 \\
JY8 & 0.210449 & 0.06347757 & 3.315 & 0.0009 \\
JY9 & 0.600007 & 0.09005596 & 6.663 & 0.0001 \\
JY10 & 0.561443 & 0.05170146 & 10.859 & 0.0001 \\
JZ1 & 0.461570 & 0.04660500 & 9.904 & 0.0001 \\
JZ2 & 0.278603 & 0.10561231 & 2.638 & 0.0083 \\
JZ3 & 0.392561 & 0.04658856 & 8.426 & 0.0001 \\
JZ4 & 0.265257 & 0.05058339 & 5.244 & 0.0001 \\
JZ5 & 0.363069 & 0.04691215 & 7.739 & 0.0001 \\
JZ6 & 0.441733 & 0.06922653 & 6.381 & 0.0001 \\
JZ7 & 0.273386 & 0.05420188 & 5.044 & 0.0001 \\
JZ8 & 0.341149 & 0.06298210 & 5.417 & 0.0001 \\
JZ9 & 0.575650 & 0.08401566 & 6.852 & 0.0001 \\
JZ10 & 0.441433 & 0.04763522 & 9.267 & 0.0001 \\
JW1 & 0.203171 & 0.03203315 & 6.343 & 0.0001 \\
JW2 & 0.070038 & 0.09816934 & 0.713 & 0.4756 \\
JW3 & 0.171103 & 0.03217120 & 5.319 & 0.0001 \\
JW4 & 0.118869 & 0.03741577 & 3.177 & 0.0015 \\
JW5 & 0.105782 & 0.03236445 & 3.268 & 0.0011 \\
JW6 & 0.304067 & 0.06284805 & 4.838 & 0.0001 \\
JW7 & 0.055058 & 0.04221763 & 1.304 & 0.1922 \\
JW8 & 0.079764 & 0.05302684 & 1.504 & 0.1325 \\
JW9 & 0.375621 & 0.07994127 & 4.699 & 0.0001 \\
JW10 & 0.119927 & 0.03182833 & 3.768 & 0.0002 \\
& & & & \\
\hline & & &
\end{tabular}

Total Number of Obsrvation Used $\quad 44,342$

Mean of the Dependent Variable $\quad 6,0497$

$\begin{array}{lll}\text { Adjusted } & \text { R - Square } & .458\end{array}$ 


\section{Definition of Variables for Table 5.A}

Dependent Variable:

$\mathrm{Ai}, \mathrm{i}=1,2,3,4$

$\mathrm{Wi}, \mathrm{i}=1,2,3$

$\mathrm{Ji}, \mathrm{i}=1,2, \ldots 10$
Natural logarithm of Family Disposable Income. Includes interest component of the net imputed rent on the stock of consumer durables. For details, see Hayashi, F., Ando, A., and Ferris, R.,"Life Cycle and Bequest Savings", NIRA Research Output, Vol. 2,No. 1, 1989; especially Table 1 and Appendices 1 and 2 .

Age of the head of the family,

$$
\begin{array}{ll}
\mathrm{i}=1 & 29 \text { or less } \\
\mathrm{i}=2 & 30 \sim 39 \\
\mathrm{i}=3 & 40 \sim 49 \\
\mathrm{i}=4 & 50 \sim 57 \\
& \text { Base is } 58 \sim 63
\end{array}
$$

Size of the employer

$$
\begin{aligned}
& i=1 \quad \text { more than } 1,000 \text { employees } \\
& i=2 \quad 1 \text { to } 29 \text { employees } \\
& i=3 \quad \text { Government } \\
& \text { Base is } 30-999 \text { employees }
\end{aligned}
$$

\section{Occupational Classification}

$$
\begin{array}{ll}
i=1 & \text { regular blue color labor } \\
i=2 & \text { temporary blue color labor } \\
i=3 & \text { private white color worker } \\
i=4 & \text { Government worker } \\
i=5 & \text { marchants and artisan } \\
i=6 & \text { Manager of own business } \\
i=7 & \text { Manager of corporation } \\
i=8 & \text { Professional } \\
i=9 & \text { other } \\
i=10 & \text { Agriculture and fishery } \\
\text { Base in family business }
\end{array}
$$

Industry in which the head of family works

$$
\begin{array}{ll}
i=1 & \text { Mining } \\
i=2 & \text { Construction } \\
i=3 & \text { Manufacturing } \\
i=4 & \text { Retail and Whole Sale } \\
i=5 & \text { Banking and Insurance } \\
i=6 & \text { Real Estate } \\
i=7 & \text { Transporting and Comm } \\
i=8 & \text { Public Utility } \\
i=9 & \text { Service } \\
i=10 & \text { Other } \\
i=11 & \text { Agriculture and Fishery } \\
\text { Base Government }
\end{array}
$$$$
\mathrm{i}=7 \quad \text { Transporting and Communication }
$$ 
Number of income earners in the family

$\mathrm{i}=1$ one earner family

$i=2$ two earner family

$i=3$ three earner family

$i=4$ four or more earner family

Base zero earner family

SEX 1

SEX 2

SEX 3

SSi

JXi

JYi

$\mathrm{JZi}$

JWi
Female headed family with spouse present

Single female aged 54 or less

Base is male headed families

\section{Main Source of Income}

$\mathrm{i}=1 \quad$ Business income

$i=2 \quad$ Wages and Salaries

$i=3 \quad$ gifts and renitence

$\mathrm{i}=4$ Pensions

Base income from capital and other

Interaction terms between $\mathrm{Al}$ and $\mathrm{Ji}$

Interaction terms between $\mathrm{A} 2$ and $\mathrm{Ji}$

Interaction terms between $\mathrm{A} 3$ and $\mathrm{Ji}$

Interaction terms between $\mathrm{A} 4$ and $\mathrm{Ji}$ 
Table 5.B

Consumption of Active Age Population

Family whose head is 63 years old or less

Dependent Variable: CON/PREDLEV

Parameter Estimates

\begin{tabular}{|r|r|r|r|r|}
\hline \multicolumn{1}{|c|}{ Variable } & $\begin{array}{c}\text { Parameter } \\
\text { Estimate }\end{array}$ & Standard Error & $\begin{array}{c}\text { T for HO: } \\
\text { Parameter }=0\end{array}$ & Prob $>|\mathrm{T}|$ \\
\hline INTERCEP & 0.307666 & 0.02140831 & 14.371 & 0.0001 \\
PERPRE & 0.291287 & 0.01137124 & 25.616 & 0.0001 \\
AR1 & 0.039875 & 0.00134011 & 29.755 & 0.0001 \\
AR2 & 0.036334 & 0.00072270 & 50.275 & 0.0001 \\
AR3 & 0.042453 & 0.00062603 & 67.812 & 0.0001 \\
AR4 & 0.038766 & 0.00074746 & 51.864 & 0.0001 \\
AR5 & 0.046410 & 0.00096680 & 48.004 & 0.0001 \\
F1 & 0.106435 & 0.00868541 & 12.254 & 0.0001 \\
F2 & 0.004464 & 0.00532026 & 0.839 & 0.4015 \\
F3 & 0.011677 & 0.00534146 & 2.186 & 0.0288 \\
F4 & 0.032177 & 0.00672943 & 4.781 & 0.0001 \\
F5 & 0.035111 & 0.00525985 & 6.675 & 0.0001 \\
F6 & 0.046917 & 0.00694144 & 6.759 & 0.0001 \\
F7 & 0.079291 & 0.01486160 & 5.335 & 0.0001 \\
L1 & 0.023688 & 0.00480293 & 4.932 & 0.0001 \\
L2 & 0.065755 & 0.00711749 & 9.239 & 0.0001 \\
H1 & 0.028969 & 0.00610076 & 4.748 & 0.0001 \\
H2 & -0.024098 & 0.00729236 & -3.305 & 0.0010 \\
H3 & -0.048643 & 0.00782666 & -6.215 & 0.0001 \\
H4 & -0.193958 & 0.01337209 & -14.505 & 0.0001 \\
DD & -0.386994 & 0.01686721 & -22.944 & 0.0001 \\
AG2 & -0.063417 & 0.00958792 & -6.614 & 0.0001 \\
AG3 & -0.095774 & 0.01112612 & -8.608 & 0.0001 \\
AG4 & -0.105030 & 0.01211308 & -8.671 & 0.0001 \\
AG5 & -0.205801 & 0.01376543 & -14.951 & 0.0001 \\
SEX & 0.318011 & 0.00954591 & 33.314 & 0.0001 \\
& & & & \\
\hline
\end{tabular}

Total Number of Observations Used

Mean of the Dependent Variable

43,444

Adjusted R - Square 


\section{Definition of Variables for Table 5.B}

CON

INTERCEP

PREDLEV

PERIN

PERPRE

$\mathrm{AGi}$

ARi

F1

F2

F3

F4

F5

F6

F7

L1

L2

H1

H2

$\mathrm{H} 3$

$\mathrm{H} 4$

DD

SEX

INVPRE
Economic Consumption. That is, expenditure an non-durables and services plus imputted gross rent on owner occupied household consumer durables.

Intercept. In this regression; since the dependent variable is a ratio of $\mathrm{CON}$ to PREDLEV, when it is rescaled by the multiplication of both sides of the equation by PREDLEV, the intercept term becomes the coefficient of PREDLEV

Prediction of family disposable income generated by the equation in Table 1.

Estimate of the life-time income. See text for discussion.

The ratio of PERIN to PREDLEV

$\mathrm{i}=1,2, \ldots, 5:$ One-zero dummies for age classes

$i=1 \quad 29$ or less

$i=2 \quad 30 \sim 39$

$\mathrm{i}=3 \quad 40 \sim 49$

$i=4 \quad 50 \sim 57$

$i=5 \quad 58-62$

$i=1,2, \ldots 5:$ Net worth of households interacted with AGi.

One-zero dummy for the presence of the spouse for the head of household

One-zero dummy for the presence of one child. (aged 18 or less)

One-zero dummy for the presence of two children

One-zero dummy for the presence of three or more children

One-zero dummy for the presence of one adult dependent, aged 19 55.

One-zero dummy for the presence of two adult dependents.

One-zero dummy for the presence of three or more dependents.

One-zero dummy for the presence of one elderly dependent, aged 56 or more

One-zero dummy for the presence of two or more elderly dependents

One-zero dummy for families living in privately owned and operated apartment or house. One-zero dummy for families living in apartment or house owned and operated by government agencies.

One-zero dummy for families living in apartment or house provided by their employers

One-zero dummy for families living in one-room apartment. Note that the base for Hi's is home owners

Let $X_{0}$ be the predetermined position in the relative distribution of PREDLEV, and the corresponding value of PREDLEV be PREDLEV 0 . For this equation, PREDLEV 0 is definied as the value of PREDLEV at 60 percentile position. Define the variable $D$ by $D$

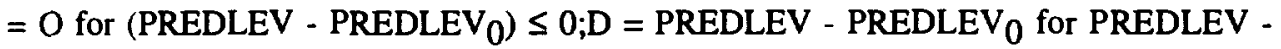
PREDLEV $_{0}>0$.Then DD is defined by $D D=D / P R E D L E V$

One-zero dummy for households headed by female (multi and single)

The reciprocal of PREDLEV 
Table 5.C

Test of Homogeneity of Consumption - Saving Behavior in Income and Wealth using Cohorts and Past Consumption.

\section{A. Regression Analysis}

Dependent Variable: The ratio of Mean saving for cohort to mean income for cohort.

Parameter Estimates

\begin{tabular}{|r|r|r|r|r|}
\hline Variable & $\begin{array}{c}\text { Parameter } \\
\text { Estimate }\end{array}$ & Standard Error & $\begin{array}{c}\text { T for HO : } \\
\text { Parameter }=0\end{array}$ & Prob > |T| \\
\hline INTERCEP & 0.515964 & 0.06845741 & 7.537 & 0.0001 \\
INVINC & -10.693550 & 14.86106354 & -0.720 & 0.4735 \\
CO79INU3 & -0.366538 & 0.13408015 & -2.734 & 0.0074 \\
CO79IN34 & -0.223609 & 0.09853119 & -2.269 & 0.0254 \\
CO79IN45 & -0.243675 & 0.09005452 & -2.706 & 0.0080 \\
CO79IN56 & -0.295923 & 0.08800982 & -3.362 & 0.0011 \\
LIFINCR & -0.088629 & 0.03980288 & -2.227 & 0.0282 \\
INCDIFU3 & 0.124945 & 0.05264678 & 2.373 & 0.0195 \\
INCDIF31 & 0.174391 & 0.08194664 & 2.128 & 0.0358 \\
INCDIF32 & 0.284368 & 0.17524082 & 1.623 & 0.1078 \\
INCDIF4 & 0.342788 & 0.08323635 & 4.118 & 0.0001 \\
INCDIF5 & 0.327651 & 0.11540302 & 2.839 & 0.0055 \\
WEAIN0 & 0.000617 & 0.02074658 & 0.030 & 0.9763 \\
WEAIN1 & -0.022308 & 0.01121007 & -1.990 & 0.0493 \\
WEAIN2 & -0.016044 & 0.00771214 & -2.080 & 0.0401 \\
WEAIN3 & 0.003591 & 0.00643586 & 0.558 & 0.5782 \\
& & & & \\
\hline
\end{tabular}

Total Number of Cohorts (Observation) : $\quad 115$

Mean of the Dependent Variable $\quad .134$

Adjusted $R^{2}$ : 


\section{Definition of Variables for Table 5.C}

Variables are always defined as arithmetic mean of the variable in question for specific cohorts.

Cohorts are defined by age of the head, occupation, and industry. In order to mach the size of cohorts as uniform as possible, some cohorts with small membership are combined with "similar" cohorts in terms of industry and occupation but always keeping age classification, while some cohorts with especially large membership are split into two or three sobcohorts by the size of income.

INTERCEP The constant term (Because the dependent variable is the ratio of saving to income, this is the estimate of the marginal propensity to save out of income).

INVINC The reciprocal of income.

CO79 The mean of consumption in 1979 for the corresponding cohort in 1979 divided by the mean income in 1984.

CO79INU3 CO79 for those aged less them 30 zero otherwise.

CO79IN34 CO79 for those aged 30 to 39 zero otherwise.

CO79IN45 CO79 for those aged 40 to 49 zero otherwise

CO79IN56 CO79 for those aged 50 to 59 zero otherwise

LIFINCR The mean of the life time income measured in 1984 divided by the mean of income in 84 .

INCDIFU3 For those cohorts aged 29 and less and whose income is more than 350 (in the unit of 10,000 ), this variable is defined by the mean of income for the cohort. Otherwise zero.

INCDIF 31 For those cohorts aged 30 to 39 and whose mean income is more than 400 (in the unit of 10,000 ), it is defined as (the mean of income for the cohort in question - 400) divided by the mean of income for the cohortOtherwise zero.

INCDIF 32 For those cohorts aged 30 to 39 and whose mean income is more than 500 (in the unit of 10,000 ), it is defined as (the mean of income for the cohort in question - 500) divided by the mean of income for the cohort. Otherwise zero.

INCDIF 5 For those cohorts aged 50 to 59, whose mean income is more than 600 (in unit of 10,000) it is defined as (the mean income for the cohort in question - 600) divided by the mean income for the cohort. Otherwise zero.

WEAIN $0 \quad$ For those cohorts aged 29 or less, this variable is defined as the ratio of the mean of net worth to the mean of income for the cohort; for other age groups, it is zero.

WEAIN 1 For those cohorts aged 30 to 39 , the variable is defined as the ratio of the mean of net worth to the mean of income for the cohort; for other age groups, it is zero.

WEAIN 2 For those cohorts aged 40 to 49, the variable is defined as the ratio of the mean of net worth to the mean of income for the cohorts, for other age groups, it is zero.

WEAIN 3 For those cohorts aged 50 to 59, the variable is defined as the ratio of the mean of income for the cohorts; for other age groups, it is zero. 


\section{Table $5 \mathrm{D}$}

\section{Characteristics of Disposable Family Income \\ Family whose head is 60 years old or more}

Includes full-time workers and those who work but did not specify full-time or parttime; Excludes part-time Workers, Unemployed, Fully-Retired and older Single Women

Dependent Variable: Logarithm of Disposable Income for family including inputed net rent on owner occupied houses and stock of consumer durables, excluding pension income.

\section{Parameter Estimates}

\begin{tabular}{|r|r|r|r|r|}
\hline Variable & $\begin{array}{c}\text { Parameter } \\
\text { Estimate }\end{array}$ & Standard Error & $\begin{array}{c}\text { T for HO: } \\
\text { Parameter }=0\end{array}$ & Prob $>|\mathrm{T}|$ \\
\hline INTERCEP & 5.075040 & 0.10894843 & 46.582 & 0.0001 \\
A1 & 0.210746 & 0.02696606 & 7.815 & 0.0001 \\
A2 & 0.079935 & 0.02928739 & 2.729 & 0.0064 \\
W1 & 0.086719 & 0.07568996 & 1.146 & 0.2520 \\
W2 & -0.130214 & 0.04948868 & -2.631 & 0.0085 \\
W3 & -0.074266 & 0.11652743 & -0.637 & 0.5239 \\
OWNER & 0.360099 & 0.04056833 & 8.876 & 0.0001 \\
FULTIM & -0.591794 & 0.19518110 & -3.032 & 0.0024 \\
AGRIC & -0.092327 & 0.12579829 & -0.734 & 0.4630 \\
J1 & 0.577672 & 0.22333841 & 2.587 & 0.0097 \\
J2 & 0.282178 & 0.29535831 & 0.955 & 0.3394 \\
J3 & 0.914155 & 0.22288484 & 4.101 & 0.0001 \\
J4 & 1.031850 & 0.25709897 & 4.013 & 0.0001 \\
J5 & -0.119097 & 0.10216874 & -1.166 & 0.2438 \\
J6 & 0.398348 & 0.11745220 & 3.392 & 0.0007 \\
J7 & 0.769920 & 0.10621362 & 7.249 & 0.0001 \\
J8 & 0.111198 & 0.11046363 & .007 & 0.3142 \\
J10 & -0.366288 & 0.15612136 & -2.346 & 0.0190 \\
N2 & 0.267479 & 0.02744211 & 9.891 & 0.0001 \\
N3 & 0.739533 & 0.03152327 & 23.460 & 0.0001 \\
N4 & 1.017702 & 0.03535620 & 28.784 & 0.0001 \\
SEC & -0.160422 & 0.04644157 & -3.454 & 0.0006 \\
& & & & \\
\hline
\end{tabular}

Total Number of Observations Used

Mean of Dependent Variable 


\section{Definition of Variables for Table 5.D}

$\mathrm{Ai}$

Wi

Owner

FMLTIM

AGRIC

$\mathrm{Ji}$

$\mathrm{Ni}$ $\mathrm{i}=1,2$ Aged of the Head of Household

$i=1 \quad 60 \sim 64$

$i=2 \quad 65 \sim 69$

Base: 70 and Over

Size of Employer, see Table I

Represents home owners,

Base: Renters

Represents those families reporting that the head of family is a full worker. Base: Those familieswho did not answer the questions on full-time employment of the head of household. Note that part-time workers and those without employment are excluded from this regression. Those who did not answer the question on full-time, part-time employment are mostly self employed. Owners of own all businesses, and their income tend to be significantly higher than the rest of the population in the same age group.

Those who are primarily engaged in agricultural activities.

Occupational Classification See Table 1

Number of Earners

$i=1 \quad$ one earner, used as base

$i=2 \quad$ two earners

$\mathrm{i}=3$ three earners

$i=4$ four or more earners

Note that, in the sample for this regression, there is no family without at least one full time earner.

Families whose head is a female (multi or single) 
Table 5. E

\section{Consumption of Elderly \\ Families whose head is Aged 60 or more and Working; \\ Report Positive Non-Pension Income and zero Pension Income \\ Home Owners}

Dependent Variable: Logarithm of Economic Consumption

Parameter Estimates:

\begin{tabular}{|r|r|r|r|r|}
\hline \multicolumn{1}{|c|}{ Variable } & $\begin{array}{c}\text { Parameter } \\
\text { Estimate }\end{array}$ & Standard Error & $\begin{array}{c}\text { T for HO: } \\
\text { Parameter }=0\end{array}$ & Prob $>|\mathrm{T}|$ \\
\hline & & & & \\
INTERCEP & 1.389281 & 0.15077734 & 9.214 & 0.0001 \\
LOGPRE & 0.156266 & 0.02856728 & 5.470 & 0.0001 \\
LOGNOPEN & 0.277233 & 0.02123535 & 13.055 & 0.0001 \\
LOGWEA1 & 0.221503 & 0.01853088 & 11.953 & 0.0001 \\
LOGWEA2 & 0.217265 & 0.01860025 & 11.681 & 0.0001 \\
LOGWEA3 & 0.217947 & 0.01847238 & 11.799 & 0.0001 \\
F1 & 0.049258 & 0.04861720 & 1.013 & 0.3112 \\
F2 & -0.022476 & 0.03901083 & -0.576 & 0.5646 \\
F3 & 0.015692 & 0.03528131 & 0.445 & 0.6566 \\
F4 & 0.074208 & 0.04328248 & 1715 & 0.0867 \\
F5 & 0.018743 & 0.02882608 & 0.650 & 0.5157 \\
F6 & 0.069928 & 0.03696025 & 1.892 & 0.0587 \\
F7 & 0.057817 & 0.04913030 & 1.177 & 0.2395 \\
L1 & 0.064595 & 0.03429294 & 1.884 & 0.0599 \\
L2 & 0.019044 & 0.10577500 & 0.180 & 0.8571 \\
SEX & 0.010129 & 0.05986134 & 0.169 & 0.8657 \\
\hline
\end{tabular}

The number of Observations Used 1145

Mean of the Dependent Variable $\quad 5.993$

$\begin{array}{ll}\text { Adjusted R - Square } & .513\end{array}$ 
Table 5. F

\section{Consumption of Elderly \\ Families whose Head is Aged 60 or more and Working Report Positive Non-Pension Income and zero Pension Income. Renters}

Dependent Variable : Logarithm of Economic Consumption

Parameter Estimates:

\begin{tabular}{|r|r|r|r|r|}
\hline \multicolumn{1}{|c|}{ Variable } & $\begin{array}{c}\text { Parameter } \\
\text { Estimate }\end{array}$ & Standard Error & $\begin{array}{c}\text { T for HO : } \\
\text { Parameter }=0\end{array}$ & Prob $>|\mathrm{T}|$ \\
\hline INTERCEP & 1.592839 & 0.51468950 & 3.095 & 0.0026 \\
LOGPRE & 0.150048 & 0.11762250 & 1.276 & 0.2055 \\
LOGNOPEN & 0.440021 & 0.11084444 & 3.970 & 0.0001 \\
LOGWEA1 & 0.046502 & 0.04248966 & 1.094 & 0.2768 \\
LOGWEA2 & 0.044377 & 0.04339745 & 1.023 & 0.3094 \\
LOGWEA3 & 0.016318 & 0.04842970 & 0.337 & 0.7370 \\
F1 & 0.185849 & 0.12778558 & 1.454 & 0.1494 \\
F2 & 0.108649 & 0.12963436 & 0.838 & 0.4043 \\
F3 & 0.195064 & 0.22468338 & 0.868 & 0.3877 \\
F5 & 0.145266 & 0.09077970 & 1.600 & 0.1132 \\
F6 & 0.352801 & 0.12941588 & 2.726 & 0.0077 \\
F7 & 1.021108 & 0.36133678 & 2.826 & 0.0058 \\
L1 & 0.265500 & 0.26721799 & 0.994 & 0.3232 \\
SEX & 0.066731 & 0.17404976 & 0.383 & 0.7024 \\
& & & & \\
\hline
\end{tabular}

The Number of Observations Used

100

Mean of the Dependent Variable 5.540

Adjusted R - Square .589 
Table 5. G

\section{Consumption of Elderly \\ Families whose Head is Aged 60 or more and working Home Owners.}

Dependent Variable: Logarithm of Economic Consumption.

Parameter Estimates

\begin{tabular}{|r|r|r|r|r|}
\hline \multicolumn{1}{|c|}{ Variable } & $\begin{array}{c}\text { Parameter } \\
\text { Estimate }\end{array}$ & $\begin{array}{c}\text { Standard } \\
\text { Error }\end{array}$ & $\begin{array}{c}\text { T for HO : } \\
\text { Parameter }=0\end{array}$ & Prob > IT \\
\hline & 1.388884 & 0.10128154 & 13.713 & 0.0001 \\
INTERCEP & 0.113744 & 0.01873201 & 6.072 & 0.0001 \\
LOGPRE & 0.135148 & 0.00798858 & 16.918 & 0.0001 \\
LOGPENS & 0.181030 & 0.00953203 & 18.992 & 0.0001 \\
LOGNOPEN & 0.266911 & 0.01251421 & 21.329 & 0.0001 \\
LOGWEA1 & 0.259436 & 0.01248517 & 20.780 & 0.0001 \\
LOGWEA2 & 0.255984 & 0.01245747 & 20.549 & 0.0001 \\
LOGWEA3 & -0.002620 & 0.02960845 & -0.089 & 0.9295 \\
F1 & 0.070128 & 0.02487239 & 2.820 & 0.0048 \\
F2 & 0.089756 & 0.02359978 & 3.803 & 0.0001 \\
F3 & 0.115086 & 0.02783413 & 4.135 & 0.0001 \\
F4 & 0.017870 & 0.01759638 & 1.982 & 0.0476 \\
F5 & 0.034870 & 3.259 & 0.0011 \\
F6 & 0.075820 & 0.02326152 & 4.108 & 0.0001 \\
F7 & 0.134912 & 0.03283756 & 2.505 & 0.0123 \\
L1 & 0.048015 & 0.01916989 & 0.214 & 0.8308 \\
L2 & 0.012690 & 0.05937698 & -0.545 & 0.5859 \\
SEX & -0.020010 & 0.03672441 & & \\
\hline
\end{tabular}

Number of Observations Used

Mean of the Dependent Variable $\quad 5.457$

$\begin{array}{lll}\text { Adjusted } \mathrm{R} \text { - Square } & .531\end{array}$ 
Table 5. H

\section{Consumption of Elderly}

Families whose Head is Aged 60 or more and Working ;

Report Positive Non-Pension Income as well as Pension Income.

\section{Renters}

Dependent Variable : Logarithm of Economic Consumption

Parameter Estimates

\begin{tabular}{|r|r|l|r|r|}
\hline Variable & $\begin{array}{l}\text { Parameter } \\
\text { Estimate }\end{array}$ & $\begin{array}{l}\text { Standard } \\
\text { Error }\end{array}$ & $\begin{array}{l}\text { T for HO : } \\
\text { Parameter }=0\end{array}$ & Prob > T| \\
\hline & & & & \\
INTERCEP & 1.699209 & 0.37934243 & 4.479 & 0.0001 \\
LOGPRE & 0.209170 & 0.07442753 & 2.810 & 0.0055 \\
LOGPENS & 0.232764 & 0.03892333 & 5.980 & 0.0001 \\
LOGNOPEN & 0.182147 & 0.04367937 & 4.170 & 0.0001 \\
LOGWEA1 & 0.116624 & 0.02976225 & 3.919 & 0.0001 \\
LOGWEA2 & 0.107687 & 0.02892041 & 3.724 & 0.0003 \\
LOGWEA3 & 0.109166 & 0.03055436 & 3.573 & 0.0005 \\
F1 & -0.037413 & 0.10809416 & -0.346 & 0.7297 \\
F2 & -0.041853 & 0.11640100 & -0.360 & 0.7196 \\
F3 & 0.332352 & 0.15463363 & 2.149 & 0.0330 \\
F4 & 0.525483 & 0.20499890 & 2.563 & 0.0112 \\
F5 & 0.135511 & 0.07432199 & 1.823 & 0.0699 \\
F6 & -0.033741 & 0.11949301 & -0.282 & 0.7780 \\
F7 & -0.372896 & 0.30569919 & -1.220 & 0.2241 \\
L1 & -0.131383 & 0.17199062 & -0.764 & 0.4459 \\
L2 & 0.989516 & 0.27829609 & 3.556 & 0.0005 \\
SEX & 0.061444 & 0.13986179 & 0.439 & 0.6610 \\
& & & & \\
\hline
\end{tabular}

Number of Observations Used

194

Mean of the Dependent Variable

5.543

Adjusted R - Square

.546 


\section{Table 5. I}

\section{Consumption of Elderly \\ Families whose Head is Aged 60 and Over and Not Working Married Couples}

Dependent Variable : Economic Consumption

Parameter Estimstes

\begin{tabular}{|r|r|r|r|r|}
\hline Variable & \multicolumn{1}{|c|}{$\begin{array}{c}\text { Parameter } \\
\text { Estimate }\end{array}$} & Standard ErTor & $\begin{array}{c}\text { T for HO : } \\
\text { Parameter }=0\end{array}$ & Prob > TT \\
\hline & & & 11.565 & 0.0001 \\
INTERCEP & 85.771388 & 7.41633548 & 16.533 & 0.0001 \\
YPENS & 0.564147 & 0.03412195 & 7.490 & 0.0001 \\
YNONPENS & 0.250387 & 0.03342921 & 15.278 & 0.0001 \\
TOTWEALT & 0.024003 & 0.00157101 & & \\
\hline
\end{tabular}

Number of Observations Used

Mean of Dependent Variable 304.87

Adjusted R - Square

.450

Table 5. J

Consumption of Elderly

Families whose Head is Aged 60 and Over and Working ;

All Households Not Included in Z, and Q.

Dependent Variable : Economic Consumption

Parameter Estimates

\begin{tabular}{|r|r|r|r|r|}
\hline Variable & \multicolumn{1}{|c|}{$\begin{array}{c}\text { Parameter } \\
\text { Estimate }\end{array}$} & Standard Error & \multicolumn{1}{c|}{$\begin{array}{c}\text { T for HO : } \\
\text { Parameter }=0\end{array}$} & Prob > |T $\mid$ \\
\hline & & & & \\
INTERCEP & 83.418744 & 14.59387087 & 12.716 & 0.0001 \\
YPENS & 0.738593 & 0.05972857 & 12.386 & 0.0001 \\
YNONPENS & 0.421536 & 0.03403296 & 0.0001 \\
TOTWEALT & 0.017999 & 0.00284655 & 6.323 & 0.0001 \\
& & & & \\
\hline
\end{tabular}

Number of Observations Used

Mean of Dependent Variable

386.90

Adjusted R - Square

.441 
Table 5. K

\section{Consumption of Elderly \\ Single Individuals Aged 60 and Over and Not Working}

Dependent Variable : Economic Consumption

Parameter Estimates

\begin{tabular}{|r|r|r|r|r|}
\hline Variable & \multicolumn{1}{|c|}{$\begin{array}{c}\text { Parameter } \\
\text { Estimate }\end{array}$} & $\begin{array}{c}\text { Standard } \\
\text { Error }\end{array}$ & $\begin{array}{c}\text { T for HO : } \\
\text { Parameter }=0\end{array}$ & Prob > |T| \\
\hline & & & 11.472 & 0.0001 \\
INTERCEP & 70.913790 & 6.18135197 & 7.070 & 0.0001 \\
YPENS & 0.438064 & 0.06195956 & 3.240 & 0.0013 \\
YNONPENS & 0.165686 & 0.05113550 & 12.130 & 0.0001 \\
TOTWEALT & 0.040621 & 0.00334871 & & \\
\hline
\end{tabular}

Number of Observations Used

532

Mean of the Dependent Variable

154.5

Adjusted R - Square

.407 
Definition of Variables for Table 5. E through 5.K

INTERCEP Constant of the Regression

PREDLEV Predicted Value of family disposable income generated by the equation in Table 2

LOGPRE Natural logarithm of PREDLEV

$\mathrm{Ai} \quad$ One-Zero dummy variables for the age of the head of household

$\mathrm{i}=1 \quad 60 \sim 64$

$\mathrm{i}=2 \quad 65 \sim 69$

$i=3 \quad 70$ and over

LOGWEAi Interaction terms between Ai's and natural logarithm of net worth of household.

Fi Same as Definitions given in Table 3.

$\mathrm{Li} \quad$ Same as Definitions given in Table 3.

SEX One - Zero dummy variable indicating families headed by a female (multi or single)

LOGNOPEN Natural Logarithm of Disposable Income of the family including imputed net rent on owner occupied houses and the stock of consumer durables, minus pension income, as reported.

LOGPENS Natural Logarithm of pensions income as reported.

YPENS Pension income of the family as reported.

YNONPEN Disposable income including inputted net rent on owner occupied houses and stock of consumer durables less pension income

TOTWEALT Net worth of the Household. 


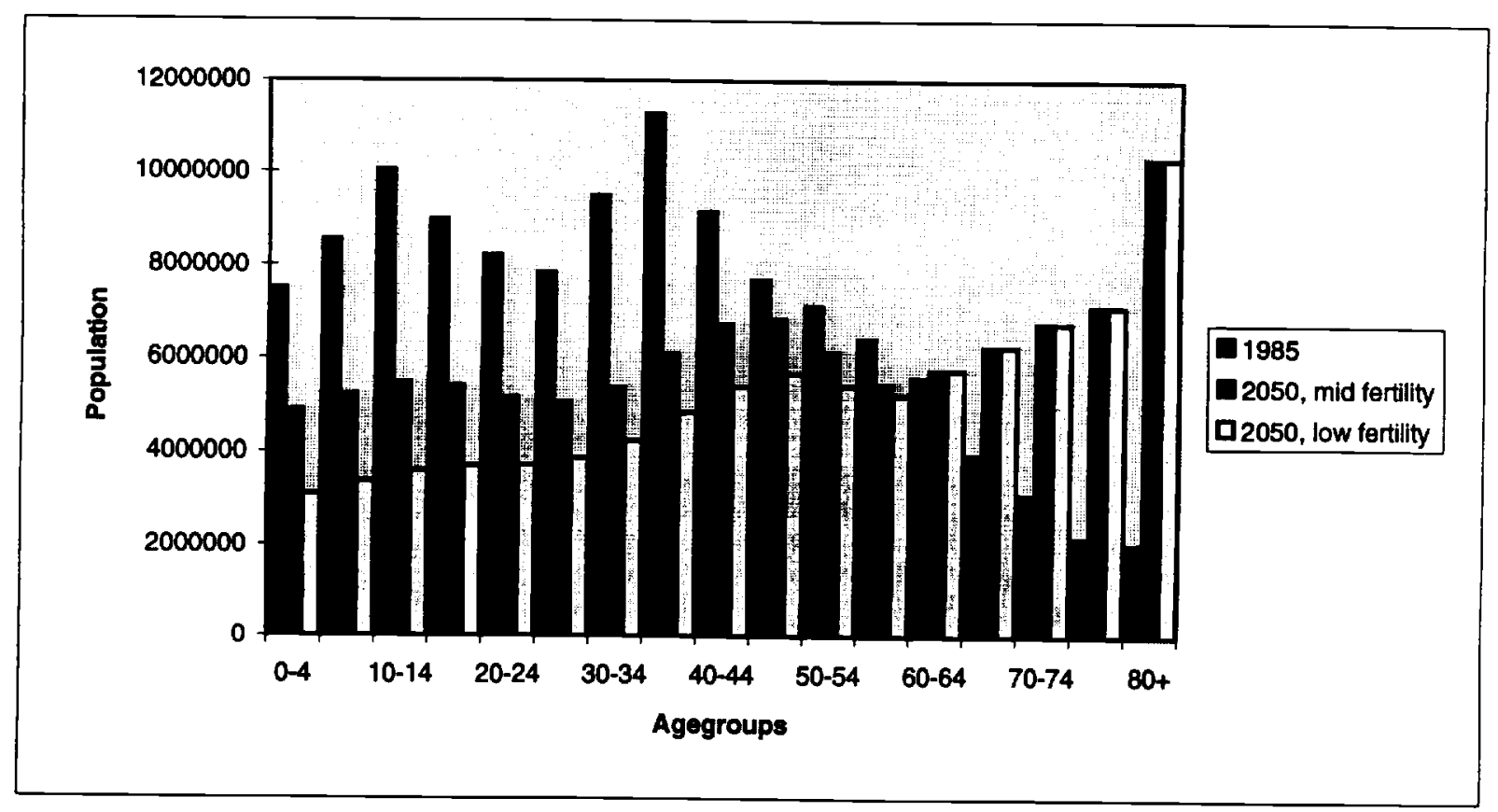

Figure A: Population by Age, 1985, 2050 - middle fertility assumption, 2050 - low fertility assumption 